\title{
AVRUPA İNSAN HAKLARI MAHKEMESININ AVRUPA KONSENSÜSÜNE BAŞVURMASI
}

\author{
DOI: $10.33717 /$ deuhfd.569971
}

Dr. Ögr. $\ddot{\text { Uyesi Ali BAL }}{ }^{*}$

\section{$\ddot{\mathbf{O} z}$}

Dünyadaki en etkili insan hakları koruma mekanizmasını kurduğu kabul edilen Avrupa İnsan Hakları Sözleşmesinin sözleşmeci devletlerin sağlamakla yükümlü olduğu hak ve özgürlükleri kavramlara dayanan ve ucu açı bir şekilde kaleme alması, Sözleşmenin uygun bir şekilde yorumlanması zaruretini doğurmaktadır. Sözleşme hükümlerini yorumlayıp uygulamada geniş bir alana sahip olan Avrupa Insan Hakları Mahkemesi, uluslararası hukukun geleneksel yorum yöntemlerini kullanmanın yanında, özerk ilke, yöntem ve teknikler de geliştirmiştir. Konsensüs tekniği, Sözleşme hükümlerinin anlamlarının ve sözleşmeci devletlerin yükümlülüklerine uyup uymadığının belirlenmesinde Mahkemenin başvurduğu en önemli araçlardan biridir. Bu çerçevede Mahkeme, sözleşmeci devletlerin hukuk ve uygulaması ile uluslararası hukuktaki ilgili gelişmeleri göz önünde bulundurarak, ele aldiğı konu hakkında bir Avrupa konsensüsünün bulunup bulunmadı̆̆ın tespit etmeye çalışmakta ve sonuca göre bir Sözleşme hükmünün anlamını ve kapsamını belirleyebilmektedir. Ne var ki, Mahkemenin buluşu olan Avrupa konsensüsünün açık bir tanımı olmadı̆̆ gibi, tespit ve uygulanmasında çeşitli tutarsızlıklar da bulunmaktadır. Dahası, Mahkemenin çoğu kez Sözleşmedeki hakları geliştirmek için başvurduğu Avrupa konsensüsünün hukukî dayanağı hususunda tereddütler ve araylşlar da vardır. Bu makalenin amacı sözü edilen konuları incelemektir.

\section{Anahtar Kelimeler}

AİHM, Avrupa konsensüsü, gelişmeci yorum ilkesi, sözleşmeci devletlerin takdir marjl, uluslararası hukukun yorum ilke ve yöntemleri, devletlerin sonraki uygulamass

Dokuz Eylül Üniversitesi Hukuk Fakültesi, Milletlerarası Hukuk Anabilim Dalı Öğretim Üyesi (e-posta: ali.bal@deu.edu.tr) (ORCID: 0000-0002-0543-0136) (Makalenin Geliş Tarihi: 01.04.2019) (Makalenin Hakemlere Gönderim Tarihleri: 02.04.201910.04.2019/Makale Kabul Tarihleri: 16.04.2019-16.04.2019) 


\title{
INVOKING EUROPEAN CONSENSUS BY THE EUROPEAN COURT OF HUMAN RIGHTS
}

\begin{abstract}
Since the Convention for the Protection of Human Rights and Fundamental Freedoms (the European Convention on Human Rights), which is accepted to have set up the most effective human rights regime, draws up the rights and freedoms that the contracting states are obliged to secure in a conceptual and open-ended manner, the Convention must be aptly interpreted. The European Court of Human Rights having a large area in interpreting and applying the Convention developed autonomous principles, methods and technics as well as using the traditional interpretation methods of international law. European consensus is one of the most important interpretative techniques that the ECtHR invokes in determining the meaning of the provisions of the Convention and whether the rights in question have been violated. In this context the ECtHR may identify whether there is a European consensus related to the matter in hand by taking into consideration relevant developments in the law and practice of the contracting states and international law, and may define the meaning and scope of a Convention provision in these premises. However European consensus, which is the creation of the ECtHR, has not been clearly defined, nor established and applied coherently. Furthermore there are various reservations and evaluations on the legal basis of European consensus mostly used to evolve and expand the rights. The purpose of this Article is to examine all the aforementioned issues.
\end{abstract}

\section{Keywords}

ECtHR, European consensus, the principle of evolutive interpretation, the margin of appreciation of the contracting states, interpretation principles and methods of international law, states' subsequent practice 


\section{GİRIŞ}

04.11.1950'de kabul edilip 03.09.1953'te yürürlüğe giren İnsan Hakları ve Temel Özgürlüklerin Korunmasına İlişkin Sözleşmeyle (Avrupa İnsan Hakları Sözleşmesi; AİHS) ${ }^{1}$ Avrupa İnsan Hakları Mahkemesinin (AİHM) kurulmasının temel amac1, m. 19'da belirtildiği üzere, taraf devletlerce üstlenilen yükümlülüklere uyulmasını sağlamaktır. Sözleşmede (ve Protokollerde) düzenlenen hak ve özgürlükler için etkili bir güvence sistemi olması hedeflenen AİHM, Sözleşmenin yorumlanması ve uygulanmasında çeşitli yöntem ve ilkeleri kullanmaktadır. Mahkeme, diğerleri yanında karşılaştırmalı yorum yöntemine de sıkça başvurarak, Sözleşmede yer alan kavramların ve hakların anlamları ile kapsamlarını ve bir hak ihlali yapılıp yapılmadığını tespit etmeye çalışmaktadır. Mahkeme, bu yöntemin bir parçası olarak, ele aldığ konuyla ilgili bir Avrupa konsensüsü başka bir deyişle ortak Avrupa yaklaşımı/standard1/paydası bulunup bulunmadığını araştırıp, bu hususta vardığ 1 sonucu, duruma göre kararın ana veya tâlî gerekçesi/gerekçelerinden biri olarak değerlendirebilmektedir.

Avrupa konsensüsünün varlığı veya yokluğu AİHM'nin tespit ve kararlarını önemli ölçüde etkilemektedir. Bununla birlikte, Mahkemenin Avrupa konsensüsünü veya bunu ifade etmekte kullandığı diğer terimleri tanımlamamış olması bir sorun olarak görülebilir. Bir ölçüde bu eksiklikle bağlantılı olarak, sözleşmeci devletlerin hukuk ve uygulamalarındaki müşterekliğin/uyuşmanın hangi düzeye ulaştığında ele alınan konuyla veya bu konuya uygulanacak Sözleşme hükmüyle ilgili bir Avrupa konsensüsü bulunduğunu tespit etmek için yeterli olacağı açık değildir. Öte yandan, diğer yorum ilke ve yöntemleri çerçevesinde birçok başka hususu da göz önünde bulunduran Mahkemenin konsensüsün varlığına veya yokluğuna her zaman aynı sonuçları bağlamadığı görülmektedir. Uygulamadaki bu gibi belirsizlik ve tutarsızlıklar, Avrupa konsensüsünün anlamı, işlevi, etkisi hakkında kategorik sonuçlara varmayı imkânsız kıldığı gibi, yoğun eleştirilere de yol açmaktadır. Kanımızca daha da önemlisi, konsensüs tekniğine başvurulmasının bizzat kendisinin meşruiyetinin tartışmaya açık olmasıdır. Bu husus, Avrupa konsensüsünün AİHS sistemi ile uluslararası hukukun kaynakları ve yorum kuralları çerçevesinde nasıl açıklanabileceğinin, neye dayandığının değerlendirilmesini gerektirmektedir.

Bkz. UNTS, 1955, Vol. 213, s. 221 vd.; RG, 19.03.1954, S. 8662. Sözleşme ana metninin 11 ve 14 No'lu Protokollerle değiştirilen nihaî hâli için bkz. http://www.echr.coe.int/ Documents/Convention_ENG.pdf; https://www.echr.coe.int/Documents/Convention TR.pdf. Çalışmamızda bu son metindeki çeviriyi esas almakla birlikte, uygun görülen değişiklikler de yapılacaktır. 
Bu çalışmada, Avrupa konsensüsünün anlamı, işlevi, birtakım belirsizliklerle birlikte uygulanması ve hukukî dayanağı, Mahkemenin içtihadı ile akademik değerlendirmeler çerçevesinde ele alınmaktadır.

\section{AVRUPA KONSENSÜSÜNÜN ANLAMI}

AİHM'nin türettiği bir kavram olan “Avrupa konsensüsü”nü (European consensus $)^{2}$ ifade etmek amacıyla değişik terimler kullanıldığı görülmektedir. Bunlar arasında Mahkemenin anlamca veya sonuç bakımından genellikle bir fark gözetmediği belirtilmelidir.

Mahkeme genellikle "konsensüs" kelimesini içeren terimleri tercih etmektedir. Bu doğrultuda, "herhangi bir Avrupa konsensüsü", "Avrupa ve dünya çapında bir konsensüs"4, "üye devletler arasında konsensüs", "sözleşmeci devletlerin esaslı çoğunluğu arasında konsensüs" (consensus amongst a substantial majority of the contracting states) ${ }^{6}$, "yerleşik (Avrupa) konsensüs(ü)" (established [European] consensus) $)^{7}$, "açık bir

2 Ziemele, Ineta: "European Consensus and International Law", in: Anne van Aaken/Iulia Motoc (eds.), The European Convention on Human Rights and General International Law, Oxford University Press, 2018, s. 23.

3 Bkz. Case of Evans v. the United Kingdom, ECHR (Grand Chamber), Judgment of 10.04.2007, p. 90; Case of Kimlya and Others v. Russia, ECHR (First Section), Judgment of 01.10.2009 (rectified on 03.12.2009) (final 01.03.2010), p. 79.

$4 \quad$ Bkz. Case of Glor v. Switzerland, ECHR (First Section), Judgment of 30.04.2009 (final 06.11.2009), p. 53.

$5 \quad$ Bkz. Case of $X, Y$ and $Z$ v. the United Kingdom, ECHR (Grand Chamber), Judgment of 22.04.1997, p. 44; Case of Kearns v. France, ECHR (Third Section), Judgment of 10.01.2008, p. 77 .

6 Bkz. Case of $A, B$ and $C$ v. Ireland, ECHR (Grand Chamber), Judgment of 16.12.2010, p. 235. Bu noktada şunu da belirtmek gerekir ki, her ne kadar 1969 tarihli Andlaşmalar Hukukuna Dair Viyana Sözleşmesinin m. 2/1(f) ve m. 2/1(g) hükümleri, "sözleşmeci/ âkit devlet" (contracting state) ile "taraf" (party) terimleri arasında belirli bir ayrım yapsa da; AİHM'nin bu terimler arasında bir anlam farkı gözetmediği ve genellikle "sözleşmeci devlet" terimini kullanmayı tercih ettiği görülmektedir. Bununla birlikte, Mahkemenin bu terimi "taraf", bir başka deyişle "andlaşmayla bağlanmaya rıza gösteren ve kendisi için andlaşmanın yürürlükte olduğu bir devlet" anlamında kullandığı açıktır. Çalışmamızda, Mahkemenin bu tercihiyle uyumlu olarak, genellikle "sözleşmeci devlet" terimi kullanılacaktır. Viyana Sözleşmesi metni için bkz. UNTS, 1980, Vol. 1155 , s. 331 vd. Sözleşmenin çevirisi için bkz. Gündüz, Aslan: Milletlerarası Hukuk Temel Belgeler Örnek Kararlar, 5. Bask1, Beta, 2003, s. 183 vd.

7 Bkz. Case of Schalk and Kopf v. Austria, ECHR (First Section), Judgment of 24.06.2010 (final 22.11.2010), p. 105; Case of S.H. and Others v. Austria, ECHR (Grand Chamber), Judgment of 03.11.2011, p. 106; Case of Khamtokhu and Aksenchik v. Russia, ECHR (Grand Chamber), Judgment of 24.01.2017, p. 85; Case of Ibrogimov v. Russia, ECHR (Third Section Committee), Judgment of 15.05.2018, p. 20. 
konsensüs" (any clear consensus) ${ }^{8}$, "geniş konsensüs" (broad consensus) $)^{9}$ ifadeleri kullanılmaktadır.

Mahkemenin yaygın şekilde tercih ettiği terimlerden bir diğeri "ortak payda"dır. Bu bağlamda, "üye devletler arasında (açık) bir ortak payda" ([clear] common ground ...) ${ }^{10}$, "sözleşmeci devletlerin ulusal hukuk sistemleri arasında ortak payda"11, "modern toplumlarda ortak payda"12 kullanılmaktadır.

Yine birçok davada Mahkeme, "yaklaşım" birliğini belirten terimleri tercih etmektedir: "ortak Avrupa yaklaşımı" (common European approach) ${ }^{13}$, "bir örnek (uniform) Avrupa yaklaşımı"14, "sözleşmeci devletler arasında genellikle paylaşılan yaklaşım" "15 vs.

Mahkemenin içtihadında bir normallik ölçüsüne işaret eden "standart" kelimesinden türetilen terimlere de sıklıkla yer verilmektedir. Mesela, "üye devletler arasında açık bir ortak standart" (any clear common standard ...) ${ }^{16}$, "sözleşmeci devletler arasında ortak standart"17, "üye devletler arasında hâkim olan standartlar" (standards prevailing ...) $)^{18}$, “ortak Avrupa standardı"19 tabirleri kullanılmaktadır.

$8 \quad$ Bkz. Case of Evans v. the United Kingdom, p. 80.

9 Bkz. Case of Sheffield and Horsham v. the United Kingdom, ECHR (Grand Chamber), Judgment of 30.07.1998, p. 55.

10 Bkz. Case of Evans v. the United Kingdom, p. 81; Case of Fretté v. France, ECHR (Third Section), Judgment of 26.02.2002 (final 26.05.2002), p. 41; Case of Schwizgebel v. Switzerland, ECHR (First Section), Judgment of 10.06.2010 (final 10.09.2010), p. 93; Case of S.A.S. v. France, ECHR (Grand Chamber), Judgment of 01.07.2014, p. 156; Case of Khamtokhu and Aksenchik v. Russia, p. 85.

11 Bkz. Case of Khamtokhu and Aksenchik v. Russia, p. 83.

12 Bkz. Case of Demir and Baykara v. Turkey, ECHR (Grand Chamber), Judgment of 12.11.2008, p. 86.

13 Bkz. Case of Sheffield and Horsham v. the United Kingdom, p. 57; Case of Christine Goodwin v. the United Kingdom, ECHR (Grand Chamber), Judgment of 11.07.2002, p. 85; Case of Shindler v. the United Kingdom, ECHR (Fourth Section), Judgment of 07.05.2013 (final 09.09.2013), p. 115.

14 Bkz. Case of Evans v. the United Kingdom, p. 79.

15 Bkz. Case of $X, Y$ and $Z$ v. the United Kingdom, p. 44, 52.

16 Bkz. Case of T. v. the United Kingdom, ECHR (Grand Chamber), Judgment of 16.12.1999, p. 72, 84 .

17 Bkz. Case of Stec and Others v. the United Kingdom, ECHR (Grand Chamber), Judgment of 12.04.2006, p. 64.

18 Bkz. Case of T. v. the United Kingdom, p. 70; Case of Kafkaris v. Cyprus, ECHR (Grand Chamber), Judgment of 12.02.2008, p. 101, 104.

19 Bkz. Case of $X, Y$ and $Z$ v. the United Kingdom, p. 44. 
Bazı davalarda ise, "görüş/düşünce" veya "eğilim" kelimelerinden türetilen terimler tercih edilmektedir: "üye devletler arasında hâkim görüş" (prevailing view ...) $)^{20}$, "uluslararası ve bölgesel düzeyde hâkim görüş"21, "günümüzde demokratik devletlerde hâkim olan düşünceler" (ideas prevailing ... $)^{22}$, "genel eğilim" (general trend) $)^{23}$, "açık bir eğilim"24, "devam eden uluslararası eğilim" 25 vs. Bunun yanında Mahkeme oldukça yeni bir kararında, "üye devletler arasında bir Avrupa konsensüsü veya en azından belirli bir eğilim" ifadesine yer vererek, eğilimin konsensüsten daha zayıf bir müşterekliği gösterebileceğine işaret etmiştir ${ }^{26}$.

Benzer başka ifadeler de kullanılmaktadır: "üye devletler arasında yeknesaklık" (uniformity ...) ${ }^{27}$, "üye devletler nezdinde destek bulma"28, "üye/sözleşmeci devletlerin hukuklarındaki yerleşik ve uzun bir geçmişi olan ilkeler" (settled and long-standing principles ...) $)^{29}$, "Avrupa devletlerinin ortak değerlerini yansıtan uygulamaları" (the practice of European states reflecting their common values) ${ }^{30}$, "taraf devletlerin uygulamalarından doğan konsensüs ve ortak değerler"31, "üye devletlerin ulusal hukuk sistemleri arasındaki büyük yakınlık" (high degree of convergence ...) $)^{32}$ vs.

20 Bkz. Case of Satık v. Turkey (No. 2), ECHR (Third Section), Judgment of 08.07.2008 (final 08.10.2008), p. 45.

$21 \quad$ Bkz. Case of Satık v. Turkey (No. 2), p. 47.

22 Bkz. Case of Bayatyan v. Armenia, ECHR (Grand Chamber), Judgment of 07.07.2011, p. 102; Case of Khamtokhu and Aksenchik v. Russia, p. 73.

23 Bkz. Case of Ünal Tekeli v. Turkey, ECHR (Fourth Section), Judgment of 16.11.2004 (final 16.02.2005), p. 62.

24 Bkz. Case of S.H. and Others v. Austria, p. 96; Case of Hristozov and Others v. Bulgaria, ECHR (Fourth Section), Judgment of 13.11.2012 (final 29.04.2013), p. 123.

25 Bkz. Case of Christine Goodwin v. the United Kingdom, p. 84-85.

26 Bkz. Case of Naït-Liman v. Switzerland, ECHR (Grand Chamber), Judgment of 15.03.2018, p. 175 .

27 Bkz. Case of Stubbings and Others v. the United Kingdom, ECHR (Chamber), Judgment of 22.10.1996, p. 54.

28 Bkz. Case of Kiyutin v. Russia, ECHR (First Section), Judgment of 10.03 .2011 (final 15.09.2011), p. 65; Case of Novruk and Others v. Russia, ECHR (Third Section), Judgment of 15.03.2016 (final 15.06.2016), p. 101; Case of Berkovich and Others v. Russia, ECHR (Third Section), Judgment of 27.03.2018 (final 27.06.2018), p. 98; Case of Ibrogimov v. Russia, p. 20.

29 Bkz. Case of S.H. and Others v. Austria, p. 96; Case of Hristozov and Others v. Bulgaria, p. 123.

30 Bkz. Case of Demir and Baykara v. Turkey, p. 85.

31 Bkz. Case of Bayatyan v. Armenia, p. 122; Case of S.A.S. v. France, p. 129.

32 Bkz. Case of Rohlena v. the Czech Republic, ECHR (Grand Chamber), Judgment of 27.01.2015, p. 33 . 
Yukarıdakilerden nisbeten farklı olarak Mahkeme bazen de konuyu "gelişmekte olan haklardan biri" (one of evolving rights) ${ }^{33}$ olarak değerlendirmektedir. $\mathrm{Bu}$ çerçevede "hukukun geçiş aşamasında" (transitional stage $)^{34}$ olduğu da belirtilebilmektedir. Yine, "üye devletler arasında ortaya ç1kmakta olan uluslararası konsensüs" (emerging international consensus ...) $)^{35}$, "ortaya çıkmakta olan konsensüs"36 " "ortaya çıkmakta olan Avrupa konsensüsü" konsensüs oluşmadığını tespit ettiği bir durumda Mahkemenin davalı devletin Sözleşmeyi ihlal etmediğine hükmetmesi beklenebilir; ancak diğer yorum yöntem ve ilkelerini de kullanan Mahkemenin vaka bazında vardığ 1 sonuç farklı olabilmektedir ${ }^{38}$. Öte yandan böyle terimlerin kullanılması, genellikle, Mahkemenin gelişmeci bir yaklaşım çerçevesinde daha yoğun bir denetim yapmak için beklemede olduğunun işaretidir.

Avrupa konsensüsünün anlamına gelince, öncelikle "konsensüs" kelimesinin sözlüklerde genel bir anlaşma/mutabakat; ortak görüş, fikir birliği şeklinde tanımlandığı belirtilmelidirr ${ }^{39}$. Bu çerçevede "Avrupa konsensüsü" de genel olarak Avrupa'daki veya daha doğrusu Avrupa Konseyi üyesi devletler arasındaki mutabakat ve fikir birliği olarak anlaşılabilir. Ne var ki bu tarif -Avrupa konsensüsü yerine veya onunla ilişkili olarak kullanılan diğer terimler gibi- söz konusu kavram hakkında belirli bir fikir verse de, AİHM'nin Avrupa konsensüsünü tam açıklamamaktadır.

33 Bkz. Case of Schalk and Kopf v. Austria, p. 105; Case of Khamtokhu and Aksenchikv. Russia, p. 85.

34 Bkz. Case of $X, Y$ and $Z$ v. the United Kingdom, p. 44; Case of Fretté v. France, p. 41; Case of Schwizgebel v. Switzerland, p. 93; Case of Khamtokhu and Aksenchik v. Russia, p. 85.

35 Bkz. Case of Chapman v. the United Kingdom, ECHR (Grand Chamber), Judgment of 18.01.2001, p. 93; Case of Lee v. the United Kingdom, ECHR (Grand Chamber), Judgment of 18.01.2001, p. 95.

36 Bkz. Case of Chapman v. the United Kingdom, p. 70; Case of Lee v. the United Kingdom, p. 72; Case of Glor v. Switzerland, p. 75; Case of S.H. and Others v. Austria, p. 96.

37 Bkz. Case of Schalk and Kopf v. Austria, p. 105; Case of S.H. and Others v. Austria, p. 96.

38 Bkz. Vanneste, Frédéric: General International Law before Human Rights Courts: Assessing the Specialty Claims of International Human Rights Law, Intersentia, 2010, s. 265-266, 292. Aşağıda göreceğimiz Christine Goodwin v. Birleşik Krallık Davası hakkındaki karar bu duruma iyi bir örnektir.

39 Bkz. The American Heritage Dictionary of the English Language, 3. Bask1, Houghton Mifflin Co., 1992, ilgili madde; Black's Law Dictionary, Bryan A. Garner (ed.), 9. Bask1, West Publishing Co., 2009, ilgili madde. 
Ayrıca belirtmek gerekir ki, bu kavramı türeten AİHM, Avrupa konsensüsünü tanımlamadığı gibi, Avrupa konsensüsünün sonuç üzerindeki etkisini de tam olarak açıklamamaktadır. Mahkemenin kavramı muğlak bırakmasının tek bir yaklaşıma bağlı kalmanın sonuçlarından kaçınmak istemesinden kaynaklandığ 1 belirtilebiliir ${ }^{40}$. Diğer taraftan, AİHM'nin yüzlerce davada başvurduğu Avrupa konsensüsünün ne olduğunu ve nasıl tespit edileceğini hâlen aydınlığa kavuşturmamasıyla bağlantılı olarak, konsensüs tekniğini açık, öngörülebilir ve işlevsel standartlar çerçevesinde uygulayamadığ 1 vurgulanmalıdır ${ }^{41}$. Bu durum da Mahkemenin kararlarının meşruiyetiyle ilgili sorunlara yol açmaktadır ${ }^{42}$.

AİHM'nin konuyla ilgili uygulaması yeknesaklık arz etmediği için, hâricen her durumda geçerli bir tanım yapmak mümkün gözükmemektedir. Yine de Mahkemenin uygulamasından yola çıkarak ana hatlarıyla bir tanım yapmak gerekirse, "Avrupa konsensüsü" belirli bir konuda sözleşmeci devletlerin bir kısmı (tercihen önemli bir çoğunluğu) tarafından benimsenen düzenleme ve/veya uygulamaların gösterdiği farazî müşterek esası ifade eder. "Konsensüs tekniği" olarak belirtilen yöntem de, böyle bir esasın varlığı veya yokluğu tespit edilip, sonuca göre Sözleşmeyi yorumlamak ve uygulamaktır.

\section{AVRUPA KONSENSÜSÜNÜN İŞLEVI}

\section{A. Genel Olarak}

AİHM, Avrupa konsensüsüne Sözleşmenin yorumlanması veya sözleşmeci devletlerin Sözleşmeyi uygularken yararlanacakları takdir marjının genişliğinin belirlenmesi amacıyla başvurmaktadır. Böylece konsensüs tekniğinin, bazı yazarların ayrı mütalaa edilmesini savunduğu "Sözleşmenin yorumlanması" ve "Sözleşmenin uygulanması" aşamalarının ${ }^{43}$ her ikisinde

40 Wildhaber, Luzius/Hjartarson, Arnaldur/Donnelly, Stephen: "No Consensus on Consensus? The Practice of the European Court of Human Rights", Human Rights Law Journal, 2013, Vol. 33, s. 249.

41 Brauch, Jeffrey A.: "The Dangerous Search for and Elusive Consensus: What the Supreme Court Should Learn from the European Court of Human Rights", Howard Law Journal, 2008-2009, Vol. 52, s. 278, 288.

42 Dzehtsiarou, Kanstantsin: European Consensus and the Legitimacy of the European Court of Human Rights, Cambridge University Press, 2015, s. 11.

43 Bu çerçevede Dijk/Hoof, Mahkemenin karar verme sürecinin genel olarak şu iki aşamadan oluştuğunu belirtmektedir: i) somut bir olayla ilgili olan Sözleşme hükmünün yorumlanması, ii) yorumlanan hükmün -ihlal edilip edilmediğini tespit etmek amaciylasomut olayın özellikleri göz önünde bulundurularak uygulanması. Dijk, P. van/Hoof, G. 
de rol oynadığı belirtilmelidir. AİHM, birçok kararda genel ilke ve esasları tespit ettikten sonra bunları olaya uygulamaya geçmekle birlikte, bahsi geçen aşamalar arasında kesin bir ayrım yapmamakta ve aynı ilke ve yöntemleri karar verme sürecinin tamamında kullanabilmektedir. Biz de aşağıdaki örnek olaylarda konsensüsün işlevini, söz konusu aşamalara göre değil, konsensüsün varlığı veya yokluğu durumuna göre inceleyeceğiz.

\section{Sözleşmenin Yorumlanması Bakımından}

Avrupa konsensüsü, amaçsal yorum, özerk yorum, lafzî yorum, sistematik yorum gibi diğer yorum ilke ve yöntemleriyle ilişkili şekilde, özellikle de gelişmeci yorumun (evolutive/dynamic interpretation) tercih edildiği durumlarda bir dayanak olarak kullanılmaktadır. Bu çerçevede Avrupa konsensüsü, Mahkemenin günün koşullarını ve bunun gerektirdiği sonucu belirlemek için başvurduğu karşılaştırmalı yorum yönteminin unsurlarından biridir. Daha açık bir deyişle, konsensüse bir konunun gelişmeci yaklaşım çerçevesinde ele alınmasının gerekip gerekmediğinin tespitinde ve bunun sonucuna göre somut olarak hangi yorumun uygun olduğuna karar verilmesinde başvurulur $^{44}$. Bir değerlendirmeye göre de konsensüs tekniği, Sözleşmenin

J. H. van: Theory and Practice of the European Convention on Human Rights, 3. Bask1, Kluwer Law International, 1998, s. 71. Senden'e göre, ilk aşamada belirli bir hakkın ne anlama geldiği (mesela "özel hayat" kavramının avlanma faaliyetlerini kapsayıp kapsamadığı) ve somut olayın söz konusu hakkın kapsamında değerlendirilip değerlendirilemeyeceği belirlenir. İkinci aşamada ise olayın özellikleri, daha kritik bir rol oynayıp, hakkın ihlal edilip edilmediğini belirlemek için ele alınır ve mesela kısıtlamaların yasayla yapılıp yapılmadığı, meşru bir amaca hizmet edip etmediği, demokratik bir toplumda gerekli olup olmadığı gibi hususlar değerlendirilir. Genel olarak ilk aşamada yorum yöntem ve ilkeleri; ikinci aşamada ise davalı devletin takdir marjı, hak ve menfaatlerin dengelenmesi gibi hususlar göz önünde bulundurulur. Senden, Hanneke Ceciel Katrijn: Interpretation of Fundamental Rights in a Multilevel Legal System: An Analysis of the European Court of Human Rights and the Court of Justice of the European Union, Doktora Tezinin Yayımlanmamış Hâli, Leiden University, 2011, s. 7-8. Vanneste, belirli bir kuralın genel ve yeknesak bir biçimde anlaşılmasını sağlamaya yönelik olan yorumlama faaliyetinin birleştirici etkisine dikkat çekmektedir. Buna mukabil, uygulamanın amacı bir kuralın somut bir olayda nasıl anlaşılması gerektiğini belirlemek olduğundan, bu aşamada olayın esası ile kurala uymadığı düşünülen müdahalenin meşru bir amaç taşıyıp taşımadığı, müdahalenin meşru amacın gerçekleştirilmesine elverişli olup olmadığı, meşru amaca ulaşmak için kullanılan aracın orantılı olup olmadığı gibi hususlar değerlendirilir. Bkz. Vanneste, s. 215-217. Son iki yazar, bu aşamaların, yöneldiği amaçlar ve uygulanan usuller bakımından birtakım farklılıklara sahip olduğunu kabul etmekle birlikte, birbirleriyle sıkı şekilde bağlantılı olduğunu, birbirlerini tamamladığını ve kesin bir şekilde ayrılmasının kolay olmadığını da belirtmektedirler.

44 Bkz. Senden, s. 137, 233, 241, 244, 262-264. Avrupa konsensüsünün gelişmeci yorum ilkesiyle sıkı şekilde bağlantılı olduğu hakkında bkz. Ziemele, s. 24. Mahkemenin, 
açık uçlu metnini tamamlamak ve hükümlerin günümüzdeki hedef ve amacını anlamak bakımından önem arz eder ${ }^{45}$.

Gelişmeci yorum ilkesi, Sözleşmenin, kabul edildiği zamanın şartlarına göre değil, güncel gelişmeler ve tutumlar ışığında yorumlanmasını öngörür. Gelişmeci yorumun, sözleşmeci devletlerin ulusal hukuk ve uygulamaları, diğer uluslararası belgeler ve/veya AİHM'nin kendi içtihadı ${ }^{46}$ temelinde ortak bir Avrupa standardı arayışıyla yakından ilgili olduğu görülmektedir ${ }^{47}$. Anlaşılacağı üzere, Sözleşmede doğrudan koruma altına alınmayan hakların Sözleşmede korunan haklar kapsamına giren yönleriyle değerlendirilip koruma altına alınmasını sağlayan gelişmeci yorum, insan hakları standartlarının değişen koşullar ve anlayışlar çerçevesinde gelişime açık tutulmasına imkân vermektedir ${ }^{48}$.

AİHM'nin Avrupa konsensüsünü zikrettiği ilk davalardan biri meşhur Tyrer v. Birleşik Krallık Davasıdır. Burada Mahkeme, 15 yaşındaki bir kişiye yargı kararıyla bedenî ceza uygulanmasını (sopayla vurulmasını) 3 . madde çerçevesinde incelerken, gelişmeci yorum ilkesine Avrupa kon-

Sözleşmeyi Avrupa'daki sosyal ve hukukî gelişmelere cevap veren ve bunları tedrîcen kapsamına alan modern bir belge olarak yorumladığı ve bu amaçla sözleşmeci devletlerin hakları geliştirici uygulamalarını araştırıp, bunlar bir Avrupa konsensüsünden söz edilecek bir kabul düzeyine ulaştığında hakların korunmasıyla ilgili standardı yükselttiği hakkında bkz. Helfer, Laurence R.: "Consensus, Coherence and the European Convention on Human Rights", Cornell International Law Journal, 1993, Vol 26, s. 134.

45 Vanneste, s. 263.

46 AİHM, içtihatlarının Avrupa'daki hukukî gelişmeleri, bu gelişmelerin de Mahkemenin sonraki kararlarını etkilediğini teyit etmektedir. Bir kararında Mahkeme, sosyal güvenliğe ilişkin uyuşmazlıklara 6. maddenin uygulanabilirliği meselesinin daha önce önüne geldiği sırada, üye devletlerin hukuk ve uygulamasında büyük bir çeşitlilik tespit ettiğini; ancak bu kararlarla başlayan hukuktaki gelişmelerin artık 6. maddedeki genel kuralların bu konularda uygulanmasının kabul edilmesine izin verdiğini belirtmiştir. Bkz. Case of Salesi v. Italy, ECHR (Chamber), Judgment of 26.02.1993, p. 19.

47 Dijk/Hoof, s. 77-78.

48 Tezcan, Durmuş/Erdem, Mustafa Ruhan/Sancakdar, Oğuz: Avrupa İnsan Hakları Sözleşmesi Işı̆ğında Türkiye'nin İnsan Hakları Sorunu, 2. Baskı, Seçkin, 2004, s. 71, 164. AİHM, AİHS'nin kendine has özellikleri bulunduğunu ve günün koşulları 1şığında yorumlanması gereken "yaşayan bir belge" (a living instrument) olduğunu vurgularken, insan haklarının korunması bakımından giderek daha yüksek standartlara ihtiyaç duyulduğuna ve bunun demokratik toplumların temel değerlerine aykırılığı değerlendirmede daha katı olmayı gerektirdiğine de dikkat çekmektedir. Bkz. Case of Selmouni v. France, ECHR (Grand Chamber), Judgment of 28.06.1999, p. 101; Case of Siliadin v. France, ECHR (Second Section), Judgment of 26.07.2005 (final 26.10.2005), p. 121, 148; Case of Rantsev v. Cyprus and Russia, ECHR (First Section), Judgment of 07.01.2010 (final 10.05.2010), p. 277 ve orada atıf yapılan kararlar. 
sensüsüyle birlikte vurgu yapmıştır. Mahkeme, Sözleşmenin günün koşulları 1şı̆̆ında yorumlanması gereken yaşayan bir belge olduğunu ve karara varırken Avrupa Konseyi üyesi devletlerin ceza politikalarındaki gelişmelerden ve onların müşterek standartlarından kaçınılmaz olarak etkileneceğini bildirmiştir $^{49}$. Buradaki yaklaşımı izleyen diğer kararlar da, çeşitli konularda farklılaşan toplumsal tutumlardan veya diğer siyasî gelişmelerden kaynaklanan Avrupa devletlerinin hukuklarındaki değişimleri yansıtmaktadır ${ }^{50}$.

AİHM'nin belirttiği üzere, Mahkeme önceki kararlarına uymak zorunda olmamakla birlikte; hukukî belirlilik, öngörülebilirlik ve hukuk önünde eşitlik ilkeleri bakımından -iyi bir gerekçe olmadıkça- önceki içtihadından ayrılmamalıdır. Bununla birlikte, Sözleşme her şeyden önce bir insan hakları koruma sistemi kurduğu içindir ki, Mahkeme sözleşmeci devletlerdeki değişen koşulları (changing conditions in contracting states) dikkate almalı ve mesela ulaşılacak standartlar bakımından ortaya çıkmakta olan konsensüsü (any emerging consensus) göz ardı etmemelidir ${ }^{51}$. Bu bağlamda Mahkeme tarafından konsensüs tekniğine bazen önceki davalarda tam aydınlatılmamış bir konuyu açıklığa kavuşturmak, bazen de önceki yorumundan farklı bir yorumu teyit etmek için başvurulur. Bu son durumda Avrupa konsensüsü, ya yeni bir yorum için bir içerik sağlamak ya da sadece yeni bir yaklaşımın gerekliliğini vurgulamak için kullanılır. Bazen de Avrupa konsensüsü, konunun Mahkeme tarafından yorumlanacak kadar olgunlaşmadığını göstermek için kullanılır ${ }^{52}$.

\section{Takdir Marjının Genişliğinin Belirlenmesi Bakımından}

Sözleşmenin yorumlanıp bir hakkın kapsamının belirlenmesinden başka, takdir marjının genişliğinin saptanması bakımından da Avrupa kon-

49 Bkz. Case of Tyrer v. the United Kingdom, ECHR (Chamber), Judgment of 24.04.1978, p. 31 .

50 Harris, David/O'Boyle, Michael/Bates, Ed/Buckley, Carla: Harris, O'Boyle and Warbrick's Law of the European Convention on Human Rights, 2. Bask1, Oxford University Press, 2009, s. 7.

51 Bkz. Case of Chapman v. the United Kingdom, p. 70; Case of Lee v. the United Kingdom, p. 72; Case of Glor v. Switzerland, p. 75. Bir başka kararında bu hususa dikkat çeken AİHM'ye göre, Mahkeme önceki içtihadıyla bağlı olmamakla birlikte, genellikle önceki kararları yönünde sonuca varmaktadır. Bu, hem hukukî belirlilik hem de içtihat hukukunun düzenli gelişimi bakımından gereklidir. Yine de Mahkeme, haklı sebepler bulunduğuna kanaat getirirse farklı bir tutum izleyebilir. Böyle bir tutum, mesela, Sözleşmenin yorumunun toplumsal değişimleri yansıtması ve günün koşullarıyla bağdaşır olması gerekliliğiyle izah edilebilir. Bkz. Case of Cossey v. the United Kingdom, ECHR (Plenary), Judgment of 27.09.1990, p. 35.

52 Bkz. Senden, s. 227, 230, 233. 
sensüsüne sıkça başvurulmaktadır. Mahkeme takdir marjı doktrinine genellikle Sözleşmedeki belirsiz ifade ve terimlerin incelendiği davalarda ya da başvuranın menfaatleri ile umumun veya diğer bireylerin menfaatleri arasında bir denge sağlamanın gerektiği durumlarda başvurmaktadır ${ }^{53}$. Takdir marjı, birtakım haklara yönelik müdahalelerin Sözleşmeye uygunluğunun değerlendirilmesinin yanında, pozitif yükümlülüklerin belirlenmesinde de göz önünde bulundurulmaktadır ${ }^{54}$.

Takdir marjı, genel olarak, AİHM'nin Sözleşmedeki yükümlülüklerini yerine getirmede ulusal otoritelere bıraktığı hareket alanını ifade $\operatorname{eder}^{55}$. Diğer bir deyişle takdir marjı doktrini, sözleşmeci devletlerin, organlarının Sözleşmede yer alan bir hakla ilgili eylemleri bakımından -Avrupa denetimi saklı kalmak üzere- bir ölçüde takdir yetkisinden yararlanmasına izin verilmesi gerektiğini öngörür. Bu doktrine başvurulması, insan haklarından ziyade devletin otoritesine ve tercihlerine saygı duyulmasına yol açabildiği için tartışmalı olsa da; yerel gerçekliklerin göz önünde bulundurulup, farklı menfaatlerin dengelenmesi ve sözleşmeci devletlerin sisteme güvenlerini sürdürmesi bakımından önem taşımaktadır. Esasen temel mesele de, devlete takdir marjı bırakılmasından çok, belirli bir olay bakımından bu doktrinin ne zaman ve nasıl uygulandığıyla ilgilidir ${ }^{56}$.

Handyside v. Birleşik Krallık Davasında Mahkeme, kişiyi müstehcen bulunan bir kitabı yayımlamaktan mahkûm etme ve söz konusu kitapları toplatma şeklindeki müdahaleleri 10. madde çerçevesinde incelerken, sözleşmeci devletlerin takdir marjının temeli, anlamı ve hangi unsurlar çerçevesinde değerlendirilebileceği hakkında önemli açıklamalar yapmıştır. Burada belirtildiği üzere, Sözleşme tarafından kurulan güvence mekanizması, insan haklarının ulusal sistemler çerçevesinde korunmasına göre ikincil niteliktedir. Sözleşme, düzenlediği hakların korunması görevini öncelikle her bir sözleşmeci devlete bırakmaktadır. Sözleşmenin kurduğu organlar ise, bu görevin yerine getirilmesine önlerine gelen davalar bakımından ve bütün iç

\footnotetext{
53 Dijk/Hoof, s. 85.
}

54 Vanneste, s. 319.

55 Jacobs, Francis G./White, Robin C. A.: The European Convention on Human Rights, 2. Bask1, Clarendon Press, 1996, s. 37; Greer, Steven: The Margin of Appreciation: Interpretation and Discretion under the European Convention on Human Rights, Council of Europe Publishing, 2000, s. 5.

56 Bkz. Harris/O'Boyle/Bates/Buckley, s. 11, 13-14. Bu noktada AİHM'den farklı olarak, nisbeten daha az istikrarlı demokrasilerdeki durumları inceleyen Amerikan İnsan Hakları Mahkemesinin, birey lehine (pro persona/pro homine) bir yaklaşım izleyerek takdir marjı doktrinine pek başvurmadığı da belirtilmelidir. Vanneste, s. 318. 
başvuru yolları tüketildikten sonra katkı sunmaktadır ${ }^{57} .10$. madde bakımından belirtmek gerekir ki, sözleşmeci devletlerin ulusal hukuklarında tek tip bir Avrupa ahlak anlayışı bulmak mümkün değildir. Ülkelerinin etkili güçleriyle doğrudan ve sürekli temas hâlinde olan devlet otoriteleri, ahlakî gerekliliklerin içeriği ile yasak ve cezaların gerekliliği hakkında fikir yürütmek hususunda uluslararası yargıçtan prensip olarak daha iyi bir konumdadır. $\mathrm{Bu}$ bakımdan söz konusu maddenin sınırsız olmasa da sözleşmeci devletlere bir takdir marjı bıraktığı açıktır. Bununla birlikte, Mahkeme bir müdahalenin ifade özgürlüğüyle bağdaştırılıp bağdaştırılamayacağı hakkında nihaî kararı vermeye yetkili olduğu için, ulusal takdir marjı Avrupa denetimiyle yan yana (hand in hand) yürümektedir ${ }^{58}$.

Mahkeme, sözleşmeci devletlere bırakılacak takdir marjının genişliğinin tespitinde hangi unsurların göz önünde bulundurulduğunu çeşitli kararlarında zikretmektedir. Mesela Mahkemeye göre, sözleşmeci devletler benzer durumlardaki farklılıkların farklı muameleyi haklı kılıp kılmadığını ve ne ölçüde haklı kıldığını değerlendirmede belirli bir takdir marjına sahiptir. Bunun kapsamı ise, koşullara, konuya, konunun arka planına ve sözleşmeci devletlerin hukukları arasında ortak bir payda bulunup bulunmadığına göre değişebilecektir ${ }^{59}$.

Mahkemenin uygulaması, genel olarak, konsensüs seviyesi azaldıça üye devletlere verilen takdir marjını arttırma yönündedir ${ }^{60}$. Daha açık şekilde belirtmek gerekirse, belirli bir konuda Sözleşmeye taraf devletlerin hukuk ve uygulamaları ortak bir paydada birleşmekteyse, AİHM'nin gelişmeci bir yaklaşım izleyip, davalı devlete dar bir takdir payı bıraktığı 1 ve taraf devletlerce üstlenilen yükümlülüklere uyulmasını sağlamak amacıyla (m. 19) daha

57 Burada gönderme yapılan ikincillik ilkesine (the principle of subsidiarity) göre, Sözleşmede düzenlenen haklara saygı duyulmasını sağlama ödevi öncelikle sözleşmeci devletlere düşer; AİHM ulusal otoriteler bu ödevi yerine getirmediğinde denetim yetkileri çerçevesinde devreye girecektir. Bkz. European Court of Human Rights/Jurisconsult, "Interlaken Follow-Up: Principle of Subsidiarity", 08.07.2010, s. 2. Bu bağlamda Sözleşme m. 1, 19 ve 35 hükümlerinin sözleşmeci devletler ile AİHM'nin yetki ve yükümlülüklerini ikincillik ilkesi temelinde öngördüğü belirtilmelidir.

58 Bkz. Case of Handyside v. the United Kingdom, ECHR (Plenary), Judgment of 07.12.1976, p. 48-49.

59 Bkz. Case of Rasmussen v. Denmark, ECHR (Chamber), Judgment of 28.11.1984, p. 40; Case of Fretté v. France, p. 40; Case of Glor v. Switzerland, p. 74-75; ve bu kararlarda atıf yapılan kararlar.

60 Bkz. Case of Lautsi and Others v. Italy, ECHR (Grand Chamber), Judgment of 18.03.2011, p. 70 . 
katı/kapsamlı bir inceleme yaptığı görülmektedir. Fakat tersi söz konusuysa, yani taraf devletlerdeki hukuk ve uygulama yeknesak olmayıp çeşitlilik göstermekteyse, Mahkeme daha geniş bir takdir yetkisi olduğuna hükmedebilmektedir ${ }^{61}$. Ancak konsensüsün varlığının gelişmeci yorum (veya çoğunluğun çözümü) lehine, konsensüsün yokluğunun ise takdir marj1 lehine sonuç doğurduğu önermesi, bazı değişik içtihatlar sebebiyle aksi ispat edilebilir bir karine olarak görülmelidir ${ }^{62}$.

$\mathrm{Bu}$ bağlamda belirtmek gerekir ki, AİHM takdir marjının genişliğini olaydan olaya değişen biçimlerde ele alabilmektedir. Avrupa konsensüsü takdir marjının genişliği tespit edilirken göz önünde bulundurulan hususlardan sadece biridir. Bunun dışında, ilgili hakkın önemi/niteliğgi; bireyin (müdahale edilen) faaliyetinin niteliği; müdahalenin amac1, niteliği ve koşulları; olayın devletin genel politikalarıyla ilgili olup olmadığı gibi etkenlere de bakılmaktadır ${ }^{63}$. Bununla birlikte, bazen bunlardan bir kısmı devlete geniş bir takdir marjı bırakılmasına işaret ederken; diğerleri aksi yönde bir sonucu destekleyebilmektedir. Bu noktada bahsi geçen temel etkenlerin takdir marj1nın belirlenmesinde ne düzeyde etkili olduğu hususunda tutarlı bir uygulamanın bulunmadığı belirtilmelidir ${ }^{64}$.

61 Bkz. Dijk/Hoof, s. 87; Benvenisti, Eyal: "Margin of Appreciation, Consensus and Universal Standards", New York University Journal of International Law \& Politics, 1998-1999, Vol. 31, s. 851; Harris/O'Boyle/Bates/Buckley, s. 9; Vanneste, s. 328; Arai-Takahashi, Yutaka: "The Margin of Appreciation Doctrine: A Theoretical Analysis of Strasbourg's Variable Geometry”, in: Andreas Føllesdal/Birgit Peters/Geir Ulfstein (eds.), Constituting Europe: The European Court of Human Rights in a National, European and Global Context, Cambridge University Press, 2013, s. 89; Letsas, George: "The ECHR as a Living Instrument: Its Meaning and Legitimacy", in: Andreas Føllesdal/Birgit Peters/Geir Ulfstein (eds.), Constituting Europe: The European Court of Human Rights in a National, European and Global Context, Cambridge University Press, 2013, s. 114-115.

62 Bkz. Dzehtsiarou, s. 27-29, 37; Londras, Fiona de/Dzehtsiarou, Kanstantsin: Great Debates on the European Convention on Human Rights, Palgrave Macmillan, 2018, s. 83.

63 Aşağıda inceleyeceğimiz davalarda takdir marjı doktrininin uygulanmasında hesaba katılan bu gibi etkenlerin spesifik olarak ne şekilde vücut bulduğu görülecektir.

64 Bkz. Brems, Eva: "The Margin of Appreciation Doctrine in the Case-Law of the European Court of Human Rights", Zeitschrift für ausländisches öffentliches Recht und Völkerrecht, 1996, Vol. 56, s. 256 vd.; Dijk/Hoof, s. 87-91; Vanneste, s. 327-330. Ayrıca belirtmek gerekir ki, yapılacak denetimin yoğunluğunun ve takdir marjının genişliğinin ve/veya aşılıp aşılmadığının belirlenmesinde Sözleşmenin bütününe nüfuz etmiş olan orantılılık ilkesi de yukarıdaki etkenlerden bir kısmıyla bağlantılı olarak değerlendirilebilmektedir. Bkz. Harris/O'Boyle/Bates/Buckley, s. 10-12; Senden, s. 239. 
Görüldüğü üzere, Avrupa konsensüsüne farklı konularda, çeşitli maddeler bakımından ve değişik amaçlarla başvurulmaktadır. Dahası konsensüsün varlığ 1 veya yokluğu, genellikle kararın tek dayanağı olmadığı için, her zaman aynı etkiyi de doğurmamaktadır. Bu uygulama çeşitliliği karşısında Avrupa konsensüsünün işlevini somut olaylar bağlamında görmek yararlı olacaktır. Hemen aşağıda ele alacağımız kararlar ${ }^{65}$, sade bir yaklaşımla, varlığı veya yokluğu durumunda Avrupa konsensüsünün nasıl bir işlev gördüğü noktasından açıklanacaktır.

\section{B. Varlığı Durumunda}

Sözleşmeci devletlerin dava edilen eylemlerinin tespit edilen Avrupa konsensüsüne uymaması genellikle Mahkemenin gelişmeci bir yaklaşım izlemesine ve birey lehine hüküm vermesine yol açmaktadır ${ }^{66}$. Ancak, konunun hassasiyetinin, müdahalenin derecesinin, telafi edicilerin varlığının vs. gözetildiği durumlarda kararlar farklı olabilmektedir.

AİHM, haksız uygulamanın durdurulması gibi bir ihtiyatî tedbir kararı verilen hazırlık davalarını (preliminary proceedings) önceleri kural olarak medenî hak ve yükümlülüklerin karara bağlanmasıyla ilgili görmeyerek 6 . maddenin güvencesi kapsamında değerlendirmemişken ${ }^{67}$, Micallef v. Malta Davasında, ihtiyatî tedbir kararlarına 6. maddenin belirli şartlarla uygulanabileceğini belirtmiştir. İçtihattaki bu değişikliğin gerekliliği, diğerleri yanında, Avrupa Konseyi üyeleri arasında m. 6'daki güvenceleri ihtiyatî tedbir kararlarına uygulamak yönünde yaygın bir konsensüs oluştuğunun gözlemlenmesiyle tespit edilmiştir ${ }^{68}$.

Scoppola v. Italya Davasında Mahkeme, işlenen suçlar bakımından sonradan çıkarılan lehe kanunun uygulanması hususunda, uluslararası hukuk çerçevesindeki gelişmelerin yanında, üye devletler arasında bu ilkeyi teyit

65 Yeri geldikçe başka kararlar da incelenecektir.

66 Pek nadiren de dava konusu müdahalenin mevcut Avrupa konsensüsüne uygun olduğu görülmektedir. Böyle bir durumda Sözleşmenin ihlal edilmediğine hükmedilmesi kuvvetle muhtemeldir. Dzehtsiarou, s. 24, 26. Mesela, bir gazeteci tarafından gizli bilgilerin ifşası için cezaî yaptırım uygulanmasını ifade özgürlüğünün düzenlendiği madde çerçevesinde değerlendirirken Mahkeme, bu tür yaptırımlara ihtiyaç olduğu hususunda üye devletlerde bir konsensüs bulunduğunu belirttikten sonra, amaç bakımından orantısız bulmadığ 1 para cezasının 10. maddeyi ihlal etmediğine karar vermiştir. Bkz. Case of Stoll v. Switzerland, ECHR (Grand Chamber), Judgment of 10.12.2007, p. 155, 161.

67 Bkz. Case of Micallef v. Malta, ECHR (Grand Chamber), Judgment of 15.10.2009, p. 75.

68 Bkz. Case of Micallef v. Malta, p. 31, 78. 
eden bir konsensüs oluştuğunu ve onun ceza hukukunun temel ilkelerinden biri hâline geldiğini kaydederek, Komisyonun 7. maddenin böyle bir koruma sağlamadığı yönündeki önceki içtihadını değiştirmiştir ${ }^{69}$.

Marckx v. Belçika Davasında evlilik dışında doğan çocuğun anneyle hukukî bağının kurulmasına ilişkin meseleler bakımından Mahkeme, Sözleşmenin kabul edildiği 1950 yılında meşru-gayrimeşru aile ayrımı yapmanın birçok Avrupa ülkesinde normal olmakla birlikte, Sözleşmenin günün koşulları 1şığında yorumlanması gerektiğini, artık üye devletlerin büyük bir çoğunluğunun ulusal hukuklarının "mater semper certa est" prensibini tanıma yönünde geliştiği gerçeğini göz ardı edemeyeceğini ve ilgili uluslararası belgelerin de evlilik içi ve evlilik dışı çocuklar arasında ayrım yapılmaması gerektiği hususunda modern toplumlarda açık bir ortak payda bulunduğunu gösterdiğini belirtmiştir ${ }^{70}$.

İrlanda hukukunun annenin hayatına yönelik bir risk bulunması durumu hariç kürtaja izin vermemesini ele aldığı $A, B$ ve $C$ v. Irlanda Davasında Mahkeme, devletin müdahalesinin başvurucuların 8. maddedeki hakları ile İlanda halkının hayatın doğası ve doğmamış çocuğun hayatının korunması hususundaki derin ahlakî değerleri arasında adil bir denge kurup kurmadığını incelerken, devletin takdir marjının genişliğinin kritik bir nokta olduğunu belirtmiştir $^{71}$. Mahkeme, aşağıda bahsedeceğimiz Evans v. Birleşik Krallık Davasında konsensüs ile takdir marjı arasındaki ilişki hakkında öngördüğü esasları burada da tekrar edip, konuyla ilgili hak ve menfaat çatışmaları arasında adil bir dengenin kurulmasında devletin prensip olarak geniş bir takdir marjından yararlandığını değerlendirmiştir ${ }^{72}$. Mahkeme, sözleşmeci devletlerin esaslı bir çoğunluğunun arasında İrlanda hukukundakinden daha çok sebeplerle kürtaja izin verilmesi yönünde bir konsensüsün bulunduğunu teyit edip, bu hususta uluslararası alandaki eğilimleri ve görüşleri ayrıca incelemeye gerek olmadığını belirtmekle birlikte, söz konusu konsensüsün devletin konuyla ilgili geniş takdir marjını kesin bir şekilde daralttığı kanaatinde değildir ${ }^{73}$.

69 Bkz. Case of Scoppola v. Italy (No. 2), ECHR (Grand Chamber), Judgment of 17.09.2009, p. 105-106, 109.

70 Bkz. Case of Marckx v. Belgium, ECHR (Plenary), Judgment of 13.06.1979, p. 41.

71 Bkz. Case of $A, B$ and $C$ v. Ireland, p. 230-231.

72 Bkz. Case of $A, B$ and $C$ v. Ireland, p. 232-233.

73 Bkz. Case of $A, B$ and $C$ v. Ireland, p. 235-237. Sonuç olarak İrlanda'da kürtaj için yabancı bir ülke gitmeye izin verildiğini ve bu konuda yeterli bilgi ve tıbbî yardım alma olanağının bulunduğunu da gözeten Mahkeme, İrlanda halkının ahlakî değerlerine dayanan dava konusu yasağı getirmekle davalı devletin takdir marjını aşmadığına karar 
Dickson v. Birleşik Krallık Davasında yapay döllenme yoluyla çocuk sahibi olmak isteyen hükümlünün talebinin reddedilmesini 8. madde çerçevesinde ele alan Mahkeme, takdir marjıla ilgili yerleşik esaslarını tekrarladıktan sonra, sözleşmeci devletlerin yarısından fazlasının hükümlü eşlerinin özel ziyaretlerine (conjugal visit) izni verdiğini, somut olayla bir ölçüde ilgili gördüğü bu gelişmeyi tasvip etmekle birlikte Sözleşmeyi sözleşmeci devletleri bu ziyaretlere izin vermeye zorlayacak şekilde yorumlamadığını belirtmiştir. Bununla birlikte, devletin dava konusu uygulamasının yarışan bireysel menfaatler ile kamunun menfaatleri arasında gerçek bir denge kurmadığı ve kısıtlamanın orantılılık ilkesini gözetmediği tespit edildiğinden, kabul edilebilir takdir marjının aşıldığı ve 8. maddenin ihlal edildiği karara bağlanmıştır ${ }^{74}$.

Bayatyan v. Ermenistan Davasında Mahkemenin belirttiği üzere, vicdanî ret hakkının tanınması konusunda, çeşitli uluslararası belgelerin kabul edilmesinin yanında, birkaç farklı uygulama bir kenara bırakılırsa üye devletlerin ulusal hukuklarındaki gelişmeler neredeyse bir konsensüs (nearly $a$ consensus/virtually general consensus) bulunduğunu göstermektedir. $\mathrm{Bu}$ sebeple Mahkeme, Komisyonun önceki içtihadından ayrılarak konuyu 9. madde kapsamında ele almayı tercih etmiştir ${ }^{75}$. Neticede, dinî kanaatleri nedeniyle askerlik hizmeti yapmayı reddeden başvurucuya alternatif bir hizmette bulunma imkânı da sunulmadan cezaî müeyyide uygulanması, özellikle demokratik bir toplumda gerekli olmadığı için, 9. maddeye aykırı bulunmuştur ${ }^{76}$.

Bir ilaç şirketine karşı açılmış tazminat davaları devam ederken yayımlanacağ 1 duyurulan bir yazının yayımlanmasının mahkemeye saygısızlık oluşturacağ 1 gerekçesiyle yasaklanması şeklindeki müdahaleyi 10. madde çerçevesinde incelerken AİHM, Handyside v. Birleşik Krallık Davasında bildirdiği takdir marjıyla ilgili esasları tekrarlamıştır. Ancak, o davada ahlakın korunmasıyla ilgili bir müdahale incelenip devlete geniş bir takdir marjı bırakılmışken; burada yargının otoritesinin korunmasına yönelik müdahale açısından aynı sonuca varılmamıştır. Zira bu davada incelenen kısıtlamanın dayandığı kavramlar nesnel kavramlar olduğu gibi, sözleşmeci

vermiştir. Bkz. Case of $A, B$ and $C$ v. Ireland, p. 241. Mahkemenin genel eğiliminden farklı bir tutum sergilediği bu karara aşağıda döneceğiz.

74 Bkz. Case of Dickson v. the United Kingdom, ECHR (Grand Chamber), Judgment of 04.12.2007, p. 78, 81-82, 85 .

75 Bkz. Case of Bayatyan v. Armenia, p. 103, 108-109. Kararda karşılaştırmalı hukuk verileri özel bir başlık altında (p. 46-49) ayrıntılı şekilde belirtilmiştir.

76 Bkz. Case of Bayatyan v. Armenia, p. 128. 
devletlerin hukuk ve uygulamaları da bu konuda oldukça esaslı bir ortak temel bulunduğunu ortaya koymaktadır ${ }^{77}$.

Bir meslek birliğine zorunlu üyelikle ilgili Sigurdur A. Sigurjónsson v. İzlanda Davasına ilişkin kararında Mahkeme, konuyu, Sözleşmenin hazırlık çalışmalarının örgütlenme özgürlüğünün negatif yönüne 11. maddede bilinçli bir şekilde yer verilmediğini gösterdiği iddiası yerine, sözleşmeci devletlerdeki durum çerçevesinde ele almayı seçmiştir. Mahkeme, sözleşmeci devletlerin büyük bir çoğunluğunun hukukunda olaydaki gibi bir zorunlu üyeliğin bulunmadığına, aksine örgütlenme özgürlüğünün negatif yönünün (bir birliğe katılmama veya birlikten ayrılma hakkının) güvence altına alındığına ve ayrıca uluslararası düzeyde de bu konuda büyümekte olan bir ortak payda bulunduğuna dikkat çekmiştir. Mahkeme, Sözleşmenin günün koşulları 1şığında yorumlanması gereken yaşayan bir belge olduğunu ve 11. maddenin bahsi geçen yönü de kapsayacak şekilde anlaşılması gerektiğini belirt$\operatorname{miştir}^{78}$. Neticede Mahkeme, maddenin 2. paragrafındaki kısıtlama gerekçeleri çerçevesinde de konuyu ele alarak, ihlal bulunduğuna hükmetmiştir.

Demir ve Baykara v. Türkiye Davasında belediye memurlarının 11. maddedeki güvencelerden yararlanma hakkının olup olmadığı meselesini ele alırken Mahkeme, maddedeki istisnaların dar yorumlanması gerektiğini ${ }^{79}$ ve ayrıca kamu görevlilerinin sendikalara katılma hakkının artık bütün sözleşmeci devletlerde tanındığını, kısıtlamaların ise sadece bazı hizmet gruplarına yönelik olduğunu belirtmiştir. Diğer dayanaklarla birlikte bu son durum da göz önünde bulundurularak, devletin idarî görevlilerinin 11. maddenin kapsamı dışında değerlendirilemeyeceği sonucuna varılmıştır ${ }^{80}$.

Bir başka davada AİHM, cinsiyetler arası eşitliğin geliştirilmesinin günümüzde Avrupa Konseyine üye devletler arasında önemli bir hedef olduğunu hatırlatmıştır. Kadın-erkek eşitliğine ilişkin uluslararası düzeydeki gelişmeler de, eşlerden her birinin kendi soyadını kullanma ya da yeni aile adının seçiminde fikir bildirme hakkının tanınmasına doğru ilerlemektedir. Dahası AİHM, Avrupa Konseyi üyesi devletler arasında karı-kocanın aile

77 Bkz. Case of Sunday Times v. the United Kingdom (No. 1), ECHR (Plenary), Judgment of 26.04.1979, p. 59.

78 Bkz. Case of Sigurdur A. Sigurjónsson v. Iceland, ECHR (Chamber), Judgment of 30.06.1993, p. 33, 35 .

79 Bkz. Case of Demir and Baykara v. Turkey, p. 97, 119.

80 Bkz. Case of Demir and Baykara v. Turkey, p. 106-107. Bu kararın Sözleşmenin yorumlanması ve konsensüs tekniği hakkında oldukça kapsamlı açıklamalarına daha sonra değinilecektir. 
adının seçiminde eşit söz hakkına sahip olması yönünde bir konsensüsün belirdiğine dikkat çekmektedir. Mahkemenin belirttiği üzere Türkiye, kadın ve erkeklerin aile içinde eşit haklara sahip olmasını sağlama yönündeki genel eğilimin dışında olmamakla birlikte, kocanın soyadının çiftin soyadı olarak kabul edilmesini ve bu nedenle kadının evlendiğinde otomatik olarak kendi soyadını kaybetmesini yasalarla öngören tek üye devlet konumundadır. Türkiye'de, eşler kabul etse bile evli kadınlar tek başına kızlık soyadlarını kullanamamaktadır ${ }^{81}$. Neticede bu uygulamanın 8 . maddeyle bağlantılı olarak 14. maddeyi ihlal ettiğine karar verilmiştir.

Bir başka davada Mahkeme, HIV-pozitif kişilerin sınır dışı edilmesinin yerleşik Avrupa konsensüsünü yansıtmadığını, diğer üyelerde destek bulmadığını, Rusya'nın da vatandaşı olmayan bu durumdaki kişileri zorunlu olarak sınır dışı eden tek üye devlet ve dünyadaki sadece birkaç devletten biri olduğunu belirtmiştir ${ }^{82}$. Mahkeme, bu kişilerin ülkeye girişi ve ülkede yerleşmesine ilişkin kısıtlamaları kaldırmaya yönelik ezici (overwhelming) Avrupa konsensüsü ve uluslararası konsensüs yanında, davalı devletin sağlık sebepleriyle farklı muameleyi haklı kılmak için zorlayıcı ve objektif gerekçeler sunamadığını da dikkate alarak, 8. maddeyle bağlantılı olarak 14. maddenin ihlal edildiğine karar vermiştir ${ }^{83}$.

Mahkeme, siyasî partilerin Mecliste temsil yetkisi kazanmaları için uygulanan \%10'luk seçim barajının 1 No'lu Protokolün 3. maddesini ihlal edip etmediğini incelediği bir davada, farklı türleri bulunan seçim barajlarının Avrupa ülkelerinde uygulandığını ancak Türkiye haricinde yalnızca üç devletin yüksek seçim barajı kabul ettiğini tespit etmiştir. Üye devletlerin seçim kanunlarındaki çeşitliliğin hiçbir seçim barajının seçim sistemi bir bütün olarak göz önünde bulundurulmadan değerlendirilemeyeceğini gösterdiğini vurgulayan Mahkeme, Türkiye'deki barajı istisnaî derecede yüksek bulsa da, söz konusu seçimlerin kendine özgü siyasi çerçevesi ile sisteme getirilen telafiler ve diğer güvenceler ${ }^{84}$ karşısında, barajın bahsi geçen maddedeki hakkın özüne zarar verdiğine ikna olmamıştır ${ }^{85}$.

$81 \quad$ Bkz. Case of Ünal Tekeli v. Turkey, p. 59-62.

82 Bkz. Case of Ibrogimov v. Russia, p. 20.

83 Bkz. Case of Ibrogimov v. Russia, p. 23. Daha önceki benzer konulu davalarda da Mahkemenin benzer bir tutum sergilediği görülmektedir. Bkz. Case of Kiyutin v. Russia, p. 65, 74; Case of Novruk and Others v. Russia, p. 101, 111.

84 Mahkeme tarafindan "orantılılık" başlı̆̆ 1 altında incelenmiştir.

85 Bkz. Case of Yumak and Sadak v. Turkey, ECHR (Grand Chamber), Judgment of 08.07.2008, p. 129, 132, 147. 


\section{Yokluğu Durumunda}

Bu başlık altında Mahkemenin bir Avrupa konsensüsünün bulunmadığını ya da tam oluşmadığını tespit ettiği olaylardan bazıları ele alınmaktadir.

Mahkeme, 2. maddedeki "herkes" teriminin bir embriyo veya cenini kapsayıp kapsamadığını incelerken, hayatın başlangıcının bilimsel ve hukukî tanımı ile söz konusu oluşumların niteliği ve statüsüne ilişkin bir Avrupa konsensüsü olmadığını tespit ederek, bunun belirlenmesinin devletlerin takdir marjı içinde kaldığını belirtmiştir. Soyut/kuramsal bir tanım yapmaktan kaçınan Mahkemeye göre olsa olsa bu oluşumların insan ırkına ait olduğu hakkında devletler arasında ortak bir payda bulunduğu kabul edilebilir ${ }^{86}$. Burada, üye devletlerin çoğunda taksirle öldürme suçunun cenine uygulanmadığ 1 da tespit edilmiştir ${ }^{87}$.

Mahkeme, cinsiyet değiştirenlerin yeni durumlarına yönelik hukukî uyarlamaların eksikliğinin öne sürüldüğ̈̈ davalarda, konuyla ilgili tam bir konsensüs bulunmadığını tespit etmekle birlikte, yaklaşımını zaman içinde değiştirmiştir. Rees v. Birleşik Krallık Davası, Cossey v. Birleşik Krallık Davası ve Sheffield ve Horsham v. Birleşik Krallı Davasında Mahkeme, cinsiyet değiştirenlerin hukukî yönden tanınması hususunda tam bir Avrupa konsensüsünün oluştuğuna kanaat getirmemekle birlikte, ilgili hukukun gelişim aşamasında olduğunu teyit etmiştir ${ }^{88}$. Başvuranın cinsiyet değişikliğinin

86 Bkz. Case of Vo v. France, ECHR (Grand Chamber), Judgment of 08.07.2004, p. 82, 84. Buradaki başvuru, yaklaşık altı aylık hamile anneye onunla aynı soyadı taşıyan bir başka hastaya uygulanması gereken müdahaleyi yaparak, kürtajı zorunlu hâle getiren doktorun taksirle öldürme suçundan mahkûm edilmemesine karşıdır. Bkz. Case of Vo v. France, p. 9-22. Doktrinde dikkat çekildiği üzere, Mahkemenin yorum aşamasında, genellikle bir müdahalenin gerekçelendirilmesi açısından yani uygulama aşamasında başvurduğu takdir marjı doktrinine burada başvurması pek rastlanır bir şey değildir. Senden, s. 234. Bir diğer görüşe göre de, bir maddenin uygulanabilirliği meselesi takdir marjına bağlı değildir. Mahkemenin görevi, konsensüsün yokluğuna rağmen, Sözleşme terimlerinin özerk içeriğinin aydınlatılmasıdır. Vanneste, s. 293, 320.

87 Bkz. Case of Vo v. France, p. 41.

$88 \mathrm{Bu}$ davalarda cinsiyet değiştirme ameliyatından sonra yeni durumları hukuken tanınmadığı (özellikle doğum kayıtlarının değiştirilmesi talepleri reddedildiği) için çeşitli hukukî zorluklarla karşılaşan ve yeni cinsiyetleriyle karşı cinsiyetten biriyle yasal bir evlilik yapamayan başvuranların iddiaları 8. ve 12. maddeler çerçevesinde incelenmiştir. $\mathrm{Bu}$ davalarda Mahkeme, bazı küçük farklarla birlikte, sözleşmeci devletlerdeki uygulama çeşitliliğini dikkate alarak, konuyla ilgili küçük bir ortak payda bulunduğunu, ortak bir Avrupa yaklaşımı olmadığını, hukukun geçiş aşamasında olduğunu ve bu sebeple devletlerin geniş bir takdir marjından yararlanacağını belirtmiştir. Dolayısıyla, 8. maddeden doğan pozitif yükümlülüklerin ihlal edilmediği yönünde hüküm kurulmuştur. 
hukukî olarak tanınmamasından ve özellikle de çalışma, sosyal güvenlik, emeklilik ve evlenme hakları bakımından tâbi tutulduğu muameleden şikâyetçi olduğu Christine Goodwin v. Birleşik Krallık Davasında ise Mahkeme, cinsiyet değişikliğinin hukukî yönden tanınmasıyla ilgili hâlen ortak bir Avrupa yaklaşımı bulunmadığını tespit etmekle birlikte, özellikle Avrupa dışındaki gelişmeleri göz önünde tutarak, 8 . ve 12. maddelerin ihlal edildiğini karara bağlamıştır ${ }^{89}$.

Schalk ve Kopf v. Avusturya Davasında başvuranlar, Sözleşmenin günün koşullarına göre yorumlanması gereken yaşayan bir belge olduğunu öngören Mahkeme içtihadına dayanarak, 12. maddenin artık aynı cinsiyetten kişilere evlenme hakkı verir şekilde anlaşılması gerektiğini öne sürmüşlerdir. Mahkeme ise, evlilik kurumunun Sözleşmenin kabulünden bu yana büyük sosyal değişiklikler geçirdiğine işaret etmekle birlikte, 47 sözleşmeci devletin sadece altısının bu tarz bir evliliğe izin verdiğini, konuyla ilgili bir

Ancak her seferinde Mahkeme, konuyla ilgili uygun hukukî önlemlere ihtiyaç olduğunun sözleşmeci devletler tarafından göz önünde bulundurulması gerektiğinin de altını çizmiştir. Bkz. Case of Rees v. the United Kingdom, ECHR (Plenary), Judgment of 17.10.1986, p. 37, 42, 47; Case of Cossey v. the United Kingdom, p. 40, 42; Case of Sheffield and Horsham v. the United Kingdom, p. 57, 60. Ayrica bu davalarda Mahkeme, 12. maddeyle güvence altına alınan evlenme hakkının biyolojik olarak farklı cinsiyetten kişiler arasındaki geleneksel evliliğe gönderme yaptığını belirtip, bu maddenin de ihlal edilmediğini kararlaştırmıştır. Bkz. Case of Rees v. the United Kingdom, p. 4851; Case of Cossey v. the United Kingdom, p. 43-48; Case of Sheffield and Horsham v. the United Kingdom, 62-70.

89 Bu kararında Mahkeme, farklı hukuk sistemleri ve gelenekleri olan sözleşmeci devletler arasında bu konuyla ilgili ortak bir Avrupa yaklaşımı bulunmamasının pek şaşırtıcı olmadığını, ikincillik ilkesi de göz önünde bulundurulduğunda sözleşmeci devletlerin geniş bir takdir marjından yararlanması gerektiğini belirtmiştir. Yine de Mahkeme, cinsiyet değiştiren kişilerin yeni cinsel kimliklerinin hukukî olarak tanınması bakımından devam etmekte olan bir uluslararası eğilim bulunduğunun açık ve tartışmasız kanıtları karşısında, ortak bir Avrupa yaklaşımının olmadığı gerçeğine daha az ağırlık vermiştir. Neticede Mahkeme, başvuranın yeni kimliğinin hukuken tanımasıyla elde edeceği menfaat yerine kamu yararı unsuruna ağırlık vermeyi gerektirecek önemli bir etken bulunmadığından, Sözleşmenin doğasında bulunan adil dengenin başvuran lehine olduğuna ve 8. maddenin ihlal edildiğine karar vermiştir. Bkz. Case of Christine Goodwin v. the United Kingdom, p. 85, 93. Ayrıca Mahkemeye göre, 12. madde bir kadın ile bir erkeğin evlenme hakkını düzenlese de, sosyal ve bilimsel gelişmeler karşısında cinsiyetin sadece biyolojik kriterlerle belirlenmesi uygun değildir. Her ne kadar cinsiyet değişikliğini tan1yan devlet sayıs1, onlara yeni cinsiyetleriyle evlenme hakk1 veren devlet sayısından az olsa da, konu tamamen sözleşmeci devletlerin takdirine bırakılamaz. Devletler evlenme koşullarını belirleyebilseler de, hiçbir durumda cinsiyet değiştirenleri evlenme hakkından yararlandırmamayı haklı gösteremez. Bkz. Case of Christine Goodwin v. the United Kingdom, p. 100, 103. 
Avrupa konsensüsü bulunmadığını ve 12. maddenin ihlal edilmediğini belirtmiştir $^{90}$.

Evans v. Birleşik Krallık Davasında Mahkemenin belirttiği üzere, Sözleşmenin 8. maddesiyle ilgili bir davada devletin yararlandığ 1 takdir marjının genişliği tespit edilirken çeşitli etkenler dikkate alınmalıdır. Olayda bireyin varlığının veya kimliğinin esaslı bir yönü söz konusu ise, devlete tanınan takdir marjı dardır. Ancak, söz konusu menfaatin önemi veya bu menfaati en iyi koruyan aracın ne olduğu konusunda Avrupa Konseyine üye devletler arasında bir konsensüs bulunmuyorsa ve özellikle hassas ahlakî veya etik meselelerin ortaya çıktığı bir olayda, takdir alanı genişleyecektir. Devletin yarışan özel menfaatler ile kamu menfaatleri veya Sözleşmede yer alan haklar arasında bir denge kurması gerektiğinde de genellikle takdir alanı geniştir $^{91}$. Ulusal hukukun, embriyonun tıbbî yoldan rahme yerleştirilmesinden önce rızasını geri çeken erkeği baba olmaya zorlayamamasının kad1nın özel hayatına saygı hakkını ihlal edip etmediği hususunun ele alındığı bu olayın ahlaken hassas bir mesele hakkında olduğuna şüphe yoktur. Başvuran tedavi sürecindeki maddî ve manevî kayıplarının daha fazla olduğuna dikkat çekerek, kendisinin 8. maddeden doğan haklarının babalıktan vazgeçeninkine göre daha ağır bastığını öne sürse de; Mahkeme bu konuda bir örnek Avrupa yaklaşımı ve açık bir konsensüs bulunmadığını belirtmiştir. Üye devletler arasında açık bir ortak payda bulunmadığı için, davalı devlete daha geniş bir takdir alanı verilmelidir. Neticede Mahkeme, bu konuda bir Avrupa konsensüsü olmamasını, ulusal hukukun açık kurallarının da yarışan menfaatler arasında adil bir denge kurduğunu göz önünde tutarak, 8. maddenin ihlal edilmediğine hükmetmiştir ${ }^{92}$.

90 Bkz. Case of Schalk and Kopf v. Austria, p. 57-58. Bunun yanında Mahkeme, bu tarz evliliklerin hukuken tanınması yönünde ortaya çıkmakta olan bir Avrupa konsensüsü bulunduğuna da işaret etmiştir. Yine de konu, hakkında yerleşik bir konsensüs bulunmayan ama gelişmekte olan haklardan biri olarak değerlendirilmeli ve devletler yasal değişiklikleri yapma zamanı bakımından takdir marjından yararlanmalıdır. Bkz. Case of Schalk and Kopf v. Austria, p. 105. Öte yandan bir başka davada belirtildiği üzere, evlilik dışındaki resmî beraberlik biçimlerine izin veren 19 devletten sadece Yunanistan ve Litvanya bunu münhasıran farklı cinsiyetten çiftlere tanımış bulunmaktadır. Tek başına bu durum Sözleşmenin ihlali anlamına gelmemekle birlikte, davalı devletin ilgili düzenlemesinde hemcins çiftleri hariç tutmasını haklı çıkarabilecek ciddî ve inandırıcı nedenler de sunamadığı görülmektedir. Bu sebeple Mahkeme, 8. maddeyle birlikte ele alınan 14. maddenin ihlal edildiğine hükmetmiştir. Bkz. Case of Vallianatos and Others v. Greece, ECHR (Grand Chamber), Judgment of 07.11.2013, p. 91-92.

91 Bkz. Case of Evans v. the United Kingdom, p. 77 ve orada atıf yapılan kararlar.

92 Bkz. Case of Evans v. the United Kingdom, p. 78-81, 90, 92. 
AİHM, cinsiyet değiştirmiş bir kişiye ebeveyn hakları verilmemesine ilişkin bir başka uyuşmazlıkta, konuyla ilgili ortak bir Avrupa standardı bulunmadığını gözlemlediğini belirtmiştir. Ayrıca donör tarafından yapay döllenme yoluyla doğan bir çocuk ile sosyal olarak baba rolünü üstlenen kişi arasındaki ilişkiler konusunda sözleşmeci devletler arasında genel olarak paylaşılan bir yaklaşım da bulunmamaktadır. Tıbbî yardımla üremenin Avrupa'da yıllardır uygulanmasına rağmen, birçok hukukî konunun tartı̧̧malı kaldığı; mesela donörün anonim kalmasının çocuğun menfaatleri için uygun olup olmayacağ 1 , çocuğun donörün kimliğini bilme hakkına sahip olup olmadığ gibi hususlarda üye devletler arasında bir konsensüs bulunmadığı görülmektedir. Üyeler arasında küçük bir ortak paydanın bulunduğu ve hukukun geçiş döneminde olduğu bu gibi durumlarda, devlete geniş bir takdir marjı bırakılmalıdır. Neticede davalı devletin 8. maddeyi ihlal etmediğine karar verilmiştir ${ }^{93}$.

AİHM, kendilerine ait arazideki karavanların içinde geleneksel hayat tarzlarını sürdürmek isteyen başvuranlara izin verilmemesi ve onlara karşı zorlama önlemlerine girişilmesi sebebiyle diğerleri yanında m. 8'in ihlal edildiği iddiasını ele aldığı davalarda, azınlık gruplarının ihtiyaçlarını tanımaya ve güvenliklerini, kimliklerini ve hayat tarzlarını korumaya yönelik olarak üye devletler arasında bir uluslararası konsensüsün ortaya çıkmakta olduğuna dikkat çekmiştir. Ancak Mahkemeye göre, bu konsensüs sözleşmeci devletlerin belirli bir durumda hangi davranış veya standartları istediğini gösterecek kadar somut değildir. Azınlıkların Korunmasına İlişkin Çerçeve Sözleşme de, genel ilkeleri ve hedefleri belirlemekle birlikte, uygulama araçları hususunda bir mutabakatı yansıtmamaktadır ${ }^{94}$.

Mahkeme, Scientology'nin 9. madde anlamında bir din olup olmadığını değerlendirirken, bunun üye devletler arasında tartışmalı bir mesele oldugunu, konuyla ilgili bir Avrupa konsensüsü bulunmadığını ve ikincillik ilkesi gereğince de yerel otoritelerin tutumunu dikkate alacağını belirtmiştir.

${ }^{93}$ Bkz. Case of $X, Y$ and $Z$ v. the United Kingdom, p. 44, 52. Yargıç De Meyer ise, mevcut olayda bir Avrupa konsensüsü bulunmadığını göz önünde tutmaya ve bunu belirten yukarıdaki kavramlar çerçevesinde izaha girişilmeye gerek olmadığı görüşündedir. Yargıca göre, burada uygulanması gereken temel ilke, bir çocuğun babası olmayan bir kişinin onun babası olarak kaydedilme hakkına sahip olmadığıdır. Bkz. Case of $X, Y$ and $Z v$. the United Kingdom, ECHR (Grand Chamber), Concurring Opinion of Judge De Meyer of 22.04.1997.

94 Bkz. Case of Chapman v. the United Kingdom, p. 93-94; Case of Lee v. the United Kingdom, p. 95-96. 
Neticede Rus makamlarının söz konusu inancı bir din olarak kabul ettiği dikkate alınarak, olayda 9. maddenin uygulanabilirliğine karar verilmiştii ${ }^{95}$.

Üniversitede öğrencilerin başörtüsü takma yasağını inceleyen Mahkemeye göre, devlet ile inançlar arasındaki ilişkiyle ilgili meselelerde -ki demokratik bir toplumda bu konudaki görüşler çeşitlidir- ulusal kural koyucuların rolüne özel bir önem vermek gerekir. Bu durum, ulusal otoritelerin yaklaşım çeşitliliği göz önünde bulundurulduğunda, eğitim kurumlarında dinî sembollerin taşınması düzenlenirken özellikle söz konusu olacaktır. Dinin toplumdaki önemi konusunda Avrupa'da tek tip bir anlayış olmadığ gibi, bir inancın kamuoyu önünde ifade edilmesinin anlam ve etkisi de zamana ve bağlama göre değişebilecektir. Bu konudaki kurallar da bir ülkeden bir diğerine göre değişebilecektir. Dolayısıyla ilgili düzenlemelerin kapsam ve biçimini belirlemek bir noktaya kadar devlete bırakılmalıdır ${ }^{96}$. Çoğunluğa muhalefet eden Yargıç Tulkens ise, karşılaştırmalı hukuk verilerinin Avrupa'da konuyla ilgili bir konsensüs olmadığını göstermediğini, aksine sözleşmeci devletlerin hiçbirinde üniversite eğitimi sırasında böyle bir engelin bulunmadığını belirtmiştir ${ }^{97}$.

Lautsi ve Diğerleri v. Italya Davasında devlet okullarında haç işareti bulunmasını m. 9 ve 1 No'lu Protokol m. 2 çerçevesinde ele alan AİHM, konunun davalı devletin takdir marjı içinde yer aldığı sonucuna varırken, konuyla ilgili bir Avrupa konsensüsü bulunmadığ gerçeğinin de bu yaklaşımı desteklediğini belirtmiştir ${ }^{98}$.

95 Bkz. Case of Kimlya and Others v. Russia, p. 79-81.

96 Bkz. Case of Leyla Şahin v. Turkey, ECHR (Grand Chamber), Judgment of 10.11.2005, p. 109.

97 Bkz. Case of Leyla Şahin v. Turkey, ECHR (Grand Chamber), Dissenting Opinion of Judge Tulkens of 10.11.2005, p. 3. Anlaşılacağı üzere çoğunluktan ayrılan yargıca göre, yasağın yokluğu bir konsensüsün varlığını göstermektedir. Gerçekten de kararın karşılaştırmalı hukuk verilerini içeren 55-65 numaralı paragrafları, bu yasağın neredeyse hiçbir sözleşmeci devletin hukuk ve uygulamasında bulunmadığını ortaya koymaktadır. Kararın diğer yargılama teknikleri bakımından da çeşitli kusurları bulunduğu belirtilmektedir. Bu son konu hakkında bkz. Altıparmak, Kerem/Karahanoğlulları, Onur: "Pyrrhus Zaferi: Leyla Şahin v. Türkiye, AİHM v. Hukuk, Düzenleyici İşlem v. Kanun", Hukuk ve Adalet Dergisi, Temmuz-Eylül 2004, S. 3, s. 249-275.

98 Bkz. Case of Lautsi and Others v. Italy, p. 70. Mahkeme, üye devletlerin devlet okullarında dinî sembollerin koyulmasıyla ilgili hukuk ve uygulamasını da incelemiştir. Bkz. Case of Lautsi and Others v. Italy, p. 26-28. Yargıç Malinverni ve Yargıç Kalaydjieva ise beyan ettikleri muhalefet şerhinde, takdir marjı doktrininin dikkatle ele alınması gerektiğini, zira takdir marjının kapsamının her olay bakımından aynı olmadığını ve söz konusu hakkın niteliği ve önemi, ihlalin ciddîliği, Avrupa konsensüsünün varlığı gibi birçok etkene bağlı olarak değişebileceğini belirtmişlerdir. Yargıçlar ayrıca söz konusu 
Babalığın reddi davasının -anneden farklı olarak- baba tarafından açılmasına süre sınırı koyulmasını 14. madde çerçevesinde incelerken Mahkeme, sözleşmeci devletlerin mevzuatlarının ortak bir paydaya işaret etmediğini ve çoğunun anne ve babanın durumlarını farklı şekilde düzenlediğini belirttikten sonra, bahsi geçen süre sınırının hukukî belirlilik sağlama ve çocuğun menfaatlerini koruma isteğiyle haklılaştırılabileceğine karar vermiştir ${ }^{99}$.

Tek başına yaşayan eşcinsel bir kişinin evlat edinme talebinin hayat tarzı gerekçe gösterilerek reddedilmesini incelerken Mahkeme, 8. maddeyle bağlantılı olarak 14. maddenin ihlal edilmediğine karar vermiştir. Mahkemeye göre, konuyla ilgili bir ortak payda yoktur. Sözleşmeci devletlerin çoğu bu kişilerin evlat edinmesini açıkça yasaklamasa da, demokratik bir toplumda görüşlerin oldukça farklı olabildiği bu gibi meseleler hakkında sözleşmeci devletlerin hukuk ve sosyal düzenlerinde bir örnek ilkeler bulunmamaktadır. Dolayısıyla ulusal otoritelerin, hakkında ortak bir standart bulunmayan ve ilgili hukukun geçiş aşamasında olduğu bu hassas konuda geniş bir takdir marjından yararlanması doğaldır. Şüphesiz bu yetki de, keyfî biçimde kullanılmamalıdır ve ayrıca Mahkemenin denetimine tâbidir ${ }^{100}$. Ayrıca, bu şekilde evlat edinmenin çocuk üzerindeki etkileri hakkında bilim camiasında bir mutabakat bulunmadığı, devletin geniş takdir marjı ve çocuğun menfaatlerinin korunması ihtiyacı göz önünde bulundurulduğunda orantıl1lık ilkesinin ihlal edilmediği de belirtilmiştir ${ }^{101}$.

Bir başka davada Mahkeme, bir kişinin mülkiyet hakkından ancak kamu yararı sebebiyle mahrum bırakılabileceği, buna karşılık özel kişiler arasında mülkiyetin zorunlu naklinin 1 No'lu Protokole aykırı olacağı iddiasını incelemiştir. $\mathrm{Bu}$ tarz bir uygulamanın da duruma göre kamu yararına yönelik olabileceğini kabul eden Mahkemenin belirttiği üzere, sözleşmeci devletlerin anayasaları, kanunları ve içtihatlarında, kamu yararı kavramının

olayda çok az üye devlette bu konunun düzenlendiğine ve dolayısıyla konuyla ilgili bir konsensüs olmadığına ilişkin kesin çıkarım yapmanın zor olduğuna dikkat çekmişlerdir. Bkz. Case of Lautsi and Others v. Italy, ECHR (Grand Chamber), Dissenting Opinion of Judge Malinverni joined by Judge Kalaydjieva of 18.03.2011, p. 1.

99 Bkz. Case of Rasmussen v. Denmark, p. 41.

100 Bkz. Case of Fretté v. France, p. 41. Bu karar üçe karşı dört oyla alınmıştır. Oldukça benzer konulu bir başka davada ise Büyük Daire, konsensüs tekniğine de başvurmadan, tam aksi yönde karar vermiştir. Bkz. Case of E.B. v. France, ECHR (Grand Chamber), Judgment of 22.01.2008.

101 Bkz. Case of Fretté v. France, p. 42. 
söz konusu uygulamayı hukuka aykırı kıldığını gösteren ortak bir ilke tespit edilememiştir ${ }^{102}$.

Mahkûmlara oy hakk1 verilmemesini "orant1l1lık" yönünden incelerken Mahkeme, Birleşik Krallık'ın bütün mahkûmları oy kullanma hakkından mahrum birakan birkaç sözleşmeci devletten biri olduğunu; ancak konuya ilişkin ortak bir Avrupa yaklaşımı bulunmadığı kabul edilse dahi, bunun tek belirleyici olmadığını belirtmiştir. Mahkemeye göre, bu konuda takdir marjı geniş olsa da, cezanın süresine, suçun ağırlık ve niteliğine ve bireysel durumlara bakmaksızın uygulanan genel, otomatik ve ayrım gözetmeyen kısıtlama, kabul edilebilir takdir marjını aşmakta ve 1 No'lu Protokolün 3. maddesini ihlal etmektedir ${ }^{103}$.

\section{AVRUPA KONSENSÜSÜNÜN UYGULANMASI}

$\mathrm{Bu}$ başlık altında, i) konsensüs tekniği kapsamında hangi kaynaklara başvurulduğu, ii) nasıl bir değerlendirmeyle konsensüsün varlığı veya yokluğunun tespit edildiği, iii) bu tespitin nihaî karar üzerindeki etkisinin ne olduğu; uygulamadaki belirsizliklerle birlikte açılanmaktadır.

i) AİHM, ele aldığ konuyla ilgili bir konsensüs bulunup bulunmadığını değerlendirirken sözleşmeci devletlerin hukuklarının, diğer andlaşmaların ve bölgesel düzenlemelerin gösterdiği hukukî konsensüsü; uzmanların konsensüsünü ve Avrupa'daki genel düşünceyi dikkate alabilmektedir ${ }^{104}$. Mahkemenin başvurduğu bu ve benzeri konsensüs türlerinden özellikle sözleşmeci devletlerin hukuk ve uygulamalarına dayanan konsensüsün gerçek Avrupa konsensüsü olduğu; uluslararası andlaşmalara veya uluslararası örgütlerin belgelerine dayanan konsensüsün daha çok "uluslararası konsensüs" olarak nitelendirilebileceği belirtilmelidir. Ancak, göz önünde bulundurulan uluslararası kaynaklar, Avrupa Konseyi çerçevesinde kabul edilen andlaşma ve belgeler veya sözleşmeci devletlerin çoğu tarafından onaylanan andlaşmalar ise, bunlara dayanan konsensüs de "Avrupa konsensüsü" olarak anılmalıdır ${ }^{105}$.

102 Bkz. Case of James and Others v. the United Kingdom, ECHR (Plenary), Judgment of 21.02.1986, p. 40.

103 Bkz. Case of Hirst v. the United Kingdom (No. 2), ECHR (Grand Chamber), Judgment of 06.10.2005, p. 81-82. Bu bağlamda dikkat çekildiği üzere, temel önemi haiz bir Sözleşme hükmünü aşırı şekilde etkileyen önlemlerin ele alındığı durumlarda, Mahkeme konuyla ilgili bir konsensüsün yokluğuna rağmen bireyin haklarını koruma yönünde cesur bir yaklaşım izleyebilir. Arai-Takahashi, s. 88.

104 Helfer, s. 139.

105 Dzehtsiarou, s. 39-40. Uzmanların görüşleri ile Avrupa kamuoyuna gelince, bunlar sadece devlet uygulamalarıyla tespit edilen konsensüsün veya oluşmakta olan konsensüsün 
Yukarıda aktarılan davalardan da görüldüğg̈ üzere Mahkeme, konsensüs tekniğini uygularken çoğu kez sözleşmeci devletlerdeki hukukî duruma gönderme yapmaktadır. Bu bağlamda, sözleşmeci devletlerin anayasaları, diğer yasa ve düzenlemeleri, mahkeme kararları vs. dikkate alınabilmektedir ${ }^{106}$.

Bunun yanında, Sözleşme hükümleri yorumlanırken sadece Sözleşme hükümlerinin referans alınmamas ${ }^{107}$ ve dünyadaki gelişmelerin göz ardı edilmemesi ${ }^{108}$ anlayışı çerçevesinde uluslararası hukuka da dayanılmaktadır. Böylece Mahkeme, birçok durumda sözleşmeci devletler arasındaki konsensüsün ve genel eğilimin varlığını göstermek veya desteklemek için uluslararası hukukun çeşitli kaynaklarına başvurmaktadır ${ }^{109}$. Gittikçe artan bir şekilde müracaat edilen uluslararası kaynaklar arasında, insan haklarına ilişkin veya başka konulu andlaşmalar, uluslararası örgütlerin kararları ve bu bağlamda soft law, Avrupa Konseyinin düzenleme ve tavsiyeleri, Avrupa Birliği hukuku, diğer uluslararası mahkemelerin içtihatları vs. bulunmak$\operatorname{tad}^{110}$. Mahkemenin uluslararası hukuku genel bir biçimde mütalaa ettiği; mesela Sözleşmeyi yorumlamak için başvurduğu andlaşmalara davalı devletin taraf olup olmamasını pek dikkate almadığı da belirtilmelidir ${ }^{111}$.

ii) Konsensüs tekniğinin doğrudan esasına yönelik -bir sonraki başlıkta ele alacağımız- sorunların yanında, uygulanma biçimi hakkında da meseleler bulunmaktadır. Bu bağlamda, gerek kullanılan verilerin gerçekliği, yeterliliği, yerindeliği gerek bu verilerin yorumlanıp değerlendirilmesinin uygunluğu tartışılmaktadır.

hukukî ilgilisini kurmak amaciyla kullanılmalıdır. Vanneste, s. 285. Bununla birlikte, mesela ifade ve basın özgürlüğünün demokratik bir toplumdaki önemine vurgu yapan Mahkeme kararları, Avrupa toplumunun temelini oluşturduğu düşünülen köklü değerlere dayanmaktadır. Harris/O'Boyle/Bates/Buckley, s. 8.

106 Bkz. Case of James and Others v. the United Kingdom, p. 40.

107 Bkz. Case of Demir and Baykara v. Turkey, p. 67.

108 Bkz. Case of Rantsev v. Cyprus and Russia, p. 273.

109 Vanneste, s. 277; Senden, s. 245. Letsas'ın dikkat çektiği üzere, son y1llardaki bazı kararlarında Mahkeme, yaşayan belge yaklaşımını sözleşmeci devletlerin ulusal hukuklarındaki gelişmelerden ziyade uluslararası hukuktaki genel eğilimlere -zaman zaman bağlayıcılığı da olmayan belgelere- ağırlık vererek ortaya koymaktadır. Bkz. Letsas, s. 115-119, 122.

110 Vanneste, s. 276-277; Dzehtsiarou, s. 48-49.

111 Schabas, William: The European Convention on Human Rights: A Commentary, Oxford University Press, 2015, s. 38-39. Aşağıda görüleceği üzere, Demir ve Baykara v. Türkiye Davasına ilişkin kararda Mahkeme bu konuya ilişkin kapsamlı açıklamalar yapmiştır. 
Mahkemenin uygulamasına bakıldığında, hangi veriler çerçevesinde ve hangi şartlar atında konsensüsün varlığına veya yokluğuna karar verildiği hususunda bir standart oluşmadığı görülmektedir. Bazı kararlarda hangi sözleşmeci devletlerdeki hukukî durumun ne kapsamda incelendiğinden neredeyse hiç söz edilmeden, oldukça genel ifadelerle; bazen de sadece birkaç devletin hukuk veya uygulaması örnek verilip -zaman zaman uluslararas1 hukukun diğer kaynakları gibi başka verilere de başvurularak- bir Avrupa konsensüsünün olduğu veya olmadığ kararlaştırılmaktadır $^{112}$.

Gerçekten de Mahkeme bazen konsensüsün varlığının veya yokluğunun dayanaklarına en azından karar metninde pek değinmemektedir. Mesela Mahkemeye göre, devletlerin bir kısmındaki yargısal uygulama, tüzel kişilerin manevî zararlarının tazmin edilme ihtimalinin göz ardı edilemeyeceğini göstermektedir ${ }^{113}$. Bir başka kararda, 8. maddede geçen "ev" (home) kelimesinin, bazı sözleşmeci devletlerde işyerlerini de kapsayacak şekilde anlaşı1dığııı belirtilmiştir ${ }^{114}$. Mahkeme, bir başka kararda, cinsiyet değiştirenlerin durumuyla ilgili olarak bazı üye devletlerin hukuklarında birtakım değişiklikler olduğuna dikkat çekmiştir ${ }^{115}$. Yine Mahkeme, birçok sözleşmeci devletin mevzuatının, davanın yoksul tarafları için atanan avukatların ücretlerinin devlet hazinesinden karşılanması yönünde bir eğilim gösterdiğini ifade etmiştir $^{116}$. Yine Mahkeme, üye devletlerin ceza politikalarındaki gelişmelerden ve müşterek standartlarından etkileneceğini bildirmekle yetinmiştir ${ }^{117}$. Meslek birliğine zorunlu üyelikle ilgili olarak ise sözleşmeci devletlerin büyük bir çoğunluğunun hukukunda olaydaki gibi bir zorunlu üyeliğin bulunmadığ 1 belirtilmiştir ${ }^{118}$. Bir başka kararda ise Mahkeme, eşcinsel bir kişinin evlat edinme talebinin hayat tarzı gerekçe gösterilerek reddedilmesini incelerken konuyla ilgili bir ortak payda bulunmadığını belirtmekle yetinmiştir $^{119}$.

Öte yandan, Mahkemenin yaptı̆̆ karşılaştırmalı incelemeyi nisbeten daha belirgin bir şekilde açıkladığı kararlarında da birtakım belirsizliklerin

112 Bkz. Senden, s. 245-249.

113 Bkz. Case of Comingersoll S.A. v. Portugal, ECHR (Grand Chamber), Judgment of 06.04.2000, p. 34.

114 Bkz. Case of Niemietz v. Germany, ECHR (Chamber), Judgment of 16.12.1992, p. 30.

115 Bkz. Case of Cossey v. the United Kingdom, p. 40.

116 Bkz. Case of Van der Mussele v. Belgium, ECHR (Plenary), Judgment of 23.11.1983, p. 40.

117 Bkz. Case of Tyrer v. the United Kingdom, p. 31.

118 Bkz. Case of Sigurdur A. Sigurjónsson v. Iceland, p. 35.

119 Bkz. Case of Fretté v. France, p. 41. 
bulunduğu görülmektedir. Mesela Mahkeme, yaklaşık on üye devletteki duruma değinerek, mağdurun fiziksel olarak direnç göstermesi şartına artık Avrupa devletlerinin yasalarında yer verilmediğine, özellikle içtihatlarda zor kullanmanın değil, rızanın yokluğunun tecavüz suçunun kurucu unsurlarından biri olarak benimsendiğine dikkat çekmiştir. Başka uluslararası kaynaklara da atıf yapan Mahkemeye göre, çağdaş standart ve eğilimlere uygun olarak, sözleşmeci devletlerin mağdurun fiziksel direnci olmasa da rızaya dayalı olmayan cinsel fiilleri 3 . ve 8 . maddeler gereğince etkili şekilde kovuşturmaları ve cezalandırmaları gerekir ${ }^{120}$.

Avrupa konsensüsünün varlığ 1 veya yokluğu tespit edilirken sistematik esaslar belirlenmeden esnek bir yaklaşım izlenmesi en çok eleştirilen konulardan biri olsa da, Mahkemenin konsensüs tekniğini zamanla geliştirdiği belirtilmelidir. Özellikle Mahkemenin altında ayrı bir araştırma biriminin (research division) kurulmasıyla birlikte, belirsiz, doğrulanmamış ve yargıçların bilgilerine/algılarına dayanan veriler yerine, sözleşmeci devletlerin hukuk ve uygulamalarını gösteren kapsamlı karşılaştırmalı verilere daha çok dayanıldığı görülmektedir ${ }^{121}$. Yakın tarihli bir karardan örnek vermek gerekirse, Fabris v. Fransa Davasında Mahkeme, incelenen devletlerin büyük çoğunluğunda (42'sinin 40'ında), çocuğun miras haklarının ebeveynlerin evli olup olmadığından bağımsız olduğunu, evlilik içinde veya dışında doğmuş çocuklara eşit muamele yapılması hususunda üye devletler arasındaki ortak paydanın uzun zaman önce oluştuğunu belirtmiştir ${ }^{122}$.

Uygulamada belirli bir gelişme gözlenmesine rağmen, yöntem bak1mından birtakım belirsizliklerin sürdüğü de göz ardı edilemez. Özellikle hangi çoğunluğun Avrupa konsensüsünün varlığına veya yokluğuna kanaat getirilmesinde yeterli olacağı sorunu önemli bir mesele olarak durmaktadır. $\mathrm{Bu}$ konuda Mahkemenin uygulaması genel geçer bir prensibin varlığını teyit edecek kadar istikrarlı değildir. Yukarıdaki örnek olaylardan da görüldüğü

120 Bkz. Case of M.C. v. Bulgaria, ECHR (First Section), Judgment of 04.12 .2003 (final 04.03.2004), p. 157-159, 166.

121 Dzehtsiarou, s. 40-41, 45. Ayrıca bkz. Harris/O'Boyle/Bates/Buckley, s. 10. Vanneste de, konsensüsün tespitindeki zayıflıklara dikkat çekerek, iş yoğunluğuna rağmen Mahkemenin en azından kritik olaylar bakımından konsensüs tekniğini geliştirmesi gerektiğini ve Mahkemenin eğiliminin de bu yönde olduğunu belirtmektedir. Vanneste, s.268270.

122 Bkz. Case of Fabris v. France, ECHR (Grand Chamber), Judgment of 07.02.2013, p. 34, 58. Mahkeme, somut olay bakımından, kullanılan araçlar ve hedeflenen amaç arasında makul bir orantı olmadığını da belirterek, 1 No'lu Protokolün 1. maddesiyle birlikte ele alınan 14. maddenin ihlal edildiğine karar vermiştir. Bkz. Case of Fabris v. France, p. 73. 
üzere konsensüsün varlığını doğrulamak için bazen on sözleşmeci devletin aynı tip uygulaması yeterli bulunmuşken, bazen altı devletinki yetersiz sayılmıştır; bazen de (özellikle önceki kararlarda) hiçbir devletin uygulaması somut olarak zikredilmeden konsensüsün varlığı tespit edilmiştir. Senden'in belirttiği üzere, matematiksel çözümler getirilmesi ve somut olayın bağlamının göz ardı edilmesi beklenemez; ancak Mahkemenin Avrupa konsensüsüne başvururken her zaman açı olmaması, belirli bir standarda göre hareket etmemesi ve olaydan olaya değişen tutumlar alması, yöntemin belirsizlik yaratan ve varılan sonuçların güvenilirliğini sarsan bir zaafıdır ${ }^{123}$. Benzer şekilde Helfer de, konsensüsün varlığını tespit etmek için sözleşmeci devletlerden kaç tanesinin aynı yönde uygulamasının olması gerektiğini her durum için geçerli bir formülle önceden belirlemenin mümkün olmadığını savunmaktadır. Bununla birlikte yazara göre, bunların en az çoğunluğunun uygulamalarının örtüşmesi Mahkeme için asgarî bir dayanak teşkil eder ${ }^{124}$.

Bir diğer belirsizlik noktası olarak vurgulamak gerekir ki, Mahkemenin önünde kapsamlı karşılaştırmalı veriler olsa dahi bunlar, yargıçlardan bazılarının konsensüsün varlığı konusunda farklı sonuçlara varmasına yol açabilmektedir ${ }^{125} . \mathrm{Bu}$ tarz bir durum, devletlerin uygulamaları arasında bazı nüanslar söz konusuysa, konunun ulusal hukuklarda somut olarak düzenlenmediği hâllerde vs. ortaya çıkabilir. Mesela, asgarî cezaî sorumluluk yaş1 hakkında üye devletler arasında açık bir ortak standart bulunmadığını tespit

123 Bkz. Senden, s. 252, 265.

124 Helfer, s. 159. Vanneste de, konsensüsün Sözleşmenin hedef ve amacına hizmet etmesi kaydıyla, bu esasın yerinde olduğu görüşündedir. Vanneste, s. 265. Öte yandan Mahkemenin, yakın tarihli Stübing v. Almanya Davasına ilişkin kararında konsensüsün varl1ğını tespit etmede çıtayı yüksek tuttuğu görülmektedir. Mahkeme, kardeşler arasında cinsel ilişkinin cezalandırılmasının 8. maddeyi ihlal ettiği iddiasını incelediği bu davada, sözleşmeci devletlerin yarısından fazlasının (düzeltilmiş şekliyle 24'ünün) bu eylemlere cezaî sorumluluk bağladığını tespit etmekle birlikte, konuyla ilgili bir konsensüsün bulunmadığını belirtmiştir. Bununla birlikte Mahkemeye göre, bu konuda cezaî yaptırım öngörmeyenler de dâhil olmak üzere bütün hukuk sistemlerinin kardeşler arasında evliliği yasaklaması, hukuk düzeninde ve bir bütün olarak toplumda bu kişiler arasındaki cinsel ilişkinin kabul edilmediği hususunda geniş bir konsensüs olduğunu ortaya koymaktadır. Bireyin özel hayatının en mahrem yönlerinden biriyle ilgili olsa da, bu tür ilişkileri nasıl karşılayacakları konusunda ulusal makamlar geniş bir takdir marjına sahiptir. Bkz. Case of Stübing v. Germany, ECHR (Fifth Section), Judgment of 12.04 .2012 (rectified on 13.04.2012) (final 24.09.2012), p. 61. Olayın ve kararın özeti için ayrıca bkz. Doğru, Osman/Nalbant, Atilla: İnsan Hakları Avrupa Sözleşmesi: Açıklama ve Önemli Kararlar, C. 2: İHAS 8, 9, 10, 11, 12, 13, 14, Ek Protokol 1-1, 1-2, 1-3 Maddeler, Council of Europe/TC Yargıtay Başkanlığı, 2013, s. 16-17.

125 Bkz. Senden, s. 250-251. 
eden Mahkeme, Birleşik Krallık cezaî sorumluluk yaşını nisbeten düşük belirleyen birkaç devletten biri olsa da, bunu (10 yaşı) orantısız bir şekilde düşük bulmamıştır ${ }^{126}$. Bu karara muhalefet eden yargıçlardan bazıları ise, 41 sözleşmeci devletin sadece dördünün İngiltere'deki gibi düşük bir sorumluluk yaşı belirlediğini hatırlatarak, cezaî sorumluluğun daha yukarı yaşlarda başlaması hususunda üye devletler arasında genel bir standart bulunduğunu öne sürmüşlerdir ${ }^{127}$.

Bir başka davada, gizli kalmak isteyen biyolojik annenin kim olduğunu öğrenme talebi reddedilen başvurucunun durumunu 8. ve 14. maddeler çerçevesinde incelerken Mahkeme, yediye karşı on oyla ihlal bulunmadığına karar vermiştir. Sözleşmeci devletlerin çoğunun Fransa'daki gibi bir mevzuata sahip olmadığını, onunki kadar katı olmasa da bu yönde düzenlemelere sahip bazı devletler bulunduğunu tespit eden Mahkemeye göre, hukuk sistemleri arasında konuyla ilgili uygulama çeşitliliği bulunması, Sözleşmedeki hakları herkese sağlamak için hangi önlemlerin uygun olacağına karar vermede devlete takdir marjı birakılmasını gerektirir ${ }^{128}$. Dahası, davalı devlet yarışan menfaatler arasında adil bir denge kurarak bu karmaşık ve hassas meselede sahip olduğu takdir marjını aşmamıştır ${ }^{129}$. Azınlığa göre ise Mahkeme, bir devletin münferit bir uygulamasına rağmen uygulama çeşitliliğine dayanmakla, Avrupa konsensüsünü tamamen yanlış bir şekilde kullanmış ve anlamsız kılmışıır ${ }^{130}$. Yine, yukarıda değindiğimiz Leyla Şahin v. Türkiye Davasında da yargıçların aynı karşılaştırmalı verilerden farklı sonuçlar çıkardığı hatırlanmalıdır.

iii) Yukarıdakilerin yanında tekniğin uygulanmasındaki bir diğer mesele de, Avrupa konsensüsünün varlığının veya yokluğunun tespit edilmesinden sonra, buna bağlanacak sonucun daha özel olarak da bunun nihaî karar üzerindeki etkisinin ne olduğu hakkındadır.

126 Bkz. Case of T. v. the United Kingdom, p. 72.

127 Bkz. Case of T. v. the United Kingdom, ECHR (Grand Chamber), Joint Partly Dissenting Opinion of Judges Pastor Ridruejo, Ress, Makarczyk, Tulkens and Butkevych of 16.12.1999, p. 1 .

128 Bkz. Case of Odièvre v. France, ECHR (Grand Chamber), Judgment of 13.02.2003, p. $19,47$.

129 Bkz. Case of Odièvre v. France, p. 49.

130 Bkz. Case of Odièvre v. France, ECHR (Grand Chamber), Joint Dissenting Opinion of Judges Wildhaber, Sir Nicolas Bratza, Bonello, Loucaides, Cabral Barreto, Tulkens and Pellonpää of 13.02.2003, p. 16. Azınlık görüşüyle aynı kanaati paylaşan Vanneste, genel bir uygulamanın konsensüsün ispatı için yeterli olduğunu, dolayısıyla devlete öncelikle dar bir takdir marjı bırakılması gerektiğini; yine de ilgili menfaatlerin niteliğinin değerlendirilmesiyle sonucun değişebileceğini belirtmektedir. Vanneste, s. 272. 
Daha önce de belirttiğimiz gibi AİHM, belirli bir sonuca varırken farklı yöntem ve ilkelere başvurup, oldukça çeşitli hususları göz önünde bulundurmaktadır. Bu bağlamda, Mahkemenin kararın ana gerekçesi (ratio decidendi) ile yeri geldiği veya faydalı görüldüğü için yapılan açıklamalar (obiter dicta) arasında tam bir ayrıma gitmediği de belirtilmelidir ${ }^{131} . \mathrm{Bu}$ durum, doğal olarak, Mahkemenin esasen neyi uyguladığı veya kararın ana gerekçelerinin neler olduğu hususunda farklı görüşlerin ortaya çıkmasına yol açmaktadır $^{132}$.

Anlaşılacağ1 üzere, Mahkemenin argümanlarından hangisinin daha öncelikli ve etkili olduğu ya da hepsinin eşit derecede mi olduğu her zaman açık değildir. Avrupa konsensüsünün etkisine gelince, bunun çoğunlukla lafzî yorum, sistematik yorum gibi diğer yorum yöntemlerine dayanan argümanlara ilaveten/onları desteklemek üzere kullanıldığı görülmektedir. $\mathrm{Bu}$ hâlde konsensüs, belirli bir sonuca varmak için kullanılan bir dizi argümandan biridir. Bunun yanında, çeşitli davalarda Avrupa konsensüsünün karara varmada belirleyici bir rol oynadığ 1 , hatta bazen sonucun neredeyse münhasıran konsensüs tekniğine dayandırıldığı da belirtilmelidir ${ }^{133}$.

\section{AVRUPA KONSENSÜSÜNÜN HUKUKÎ NITELIĞİ VE DAYANAĞI}

\section{A. Meşruiyet Sorununa İlişkin Tespit ve Öneriler}

Yukarıda açıkladığımız üzere, konsensüs tekniğinin işlevlerinden biri, Sözleşmenin gelişmeci bir şekilde yorumlanmasını sağlamaktır. Gelişmeci yorum ilkesi, Sözleşmede öngörülen hak ve özgürlüklerin geliştirilmesini ve

131 Harris/O'Boyle/Bates/Buckley, s. 17.

132 Aşağıda aktaracağımız üzere Mahkeme (Büyük Daire) Demir ve Baykara v. Türkiye Davasında Sözleşmeyi yorumlarken neleri esas aldığını ayrıntılarıyla açıklamıştır. $\mathrm{Bu}$ açıklamalar, 2. Dairenin -konuyu ele alırken- Avrupa Sosyal Şartının Türkiye'nin taraf olmadığı (örgütlenme ve toplu pazarlık haklarını öngören) hükümlerine de çeşitli göndermeler yapmasına Türkiye'nin itiraz etmesi karşısında gerekli görülmüştür. Türkiye'ye göre, Mahkeme, Sözleşmede yer almayan yükümlülükleri yorum yoluyla ihdas edemez. 2. Dairenin Avrupa Sosyal Şartının bahsi geçen maddelerine ve Şartın denetim organının içtihadına büyük bir önem atfettiği de dikkate alındığında başvurunun konu bakımından (ratione materiae) kabul edilemez bulunması gerekir. Bkz. Case of Demir and Baykara v. Turkey, p. 54. Başvuranlar ise 2. Dairenin uyuşmazlıkta Şartın belirtilen hükümlerini uygulamadığını, Sözleşmenin 11. maddesinin yorumunda Şartın denetim organının örgütlenme ve toplu pazarlık hakkı arasındaki bağlantıyla ilgili görüşünü dikkate aldığını belirtmişlerdir. Bkz. Case of Demir and Baykara v. Turkey, p. 63.

133 Bkz. Senden, s. 230, 259, 264. Konsensüsün varlığ1 veya yokluğunun birçok davada nihaî kararı doğrudan etkilediği hakkında ayrıca bkz. Dzehtsiarou, s. 44. 
etkili kılınmasını sağlaması yönünden genel olarak takdirle karşılanmakla birlikte ${ }^{134}$; ilkenin dayanağı, uygulanma biçimi ve meşruiyeti hakkında başta Mahkeme yargıçları arasında olmak üzere doktrinde ciddî fikir ayrılıkları da bulunmaktadır. Gelişmeci yorumun meşruiyeti hakkında kesin bir karara varmak çalışmamızın amacı olmamakla birlikte, sorun ana hatlarıyla açıklanmalidir.

Gelişmeci bir yaklaşım benimsediği durumlarda Mahkemenin hangi noktada Sözleşmeyi yorumlamaktan Sözleşmeyi değiştirmeye geçtiği hususu temel sorunlardan biridir. Bu çerçevede, gelişmeci yorum ilkesinin uygulanmasında başta Sözleşmenin lafzının gösterdikleri olmak üzere birtakım sınırlara uyulması gerektiği genellikle kabul edilmektedir. Ne var ki, sınırın tam olarak hangi noktalardan geçeceği hususunda Mahkemenin içtihadı tutarlılık arz etmemektedir ${ }^{135}$. Dahası, Mahkemenin birçok kararında uyguladığı gelişmeci yorum ilkesini tam olarak gerekçelendirdiği ve bu ilkenin dayanakları, yararları ve zararlarıyla ilgili bütün ayrıntıları verdiği de öne sürülemez ${ }^{136}$.

Gelişmeci yorumu uygulamakla ve/veya uygulama biçimiyle yargısal aktivizme sapmak ${ }^{137}$, devletin rızasını gölgelemek ve kararların meşruiyetini zedelemek, Mahkemeye yöneltilen temel eleştirilerdir ${ }^{138}$. Daha geniş bir şekilde belirtmek gerekirse, ağırlıklı görüşe göre gelişmeci yorum ilkesi

134 Bkz. Çavuşoğlu, Naz: “İnsan Hakları Avrupa Sözleşmesi’ni 'Yaşayan Belge' Yapan Yorum Teknikleri", İnsan Hakları Y1llı̆̆1, 1992, S. 14, s. 132, 137, 142-143; Gözübüyük, Şeref/Gölcüklü, Feyyaz: Avrupa İnsan Hakları Sözleşmesi ve Uygulamas1, 5. Bask1, Turhan, 2004, s. 51; Dzehtsiarou, s. 150, 155.

135 Dijk/Hoof, s. 79. Başka bir deyişle, Mahkemenin Sözleşmeyi yorumlamak yerine yeni bir kural getirmesi meşru olmadığı için, bu iki durumun birbirinden ayrılması gerekir; ancak özellikle genel ifadelerle düzenlenmiş hükümler bakımından belirli bir tercihin yorumlama mı yoksa kural ihdası mı olduğunu saptamak zordur. Bu sebeple Mahkemenin bazı kararlarındaki yaklaşımları, kimileri tarafından Sözleşmedeki güvencelerin içinde üstü kapalı şekilde yer alan bir yükümlülüğü ortaya çıkarmak olarak; kimileri tarafından ise Sözleşmeyi kapsamının dışına çıkarmak ve yeni bir yükümlülük tesis etmek olarak değerlendirilebilmektedir. Harris/O'Boyle/Bates/Buckley, s. 7-8. Yakın tarihli bir karara kısmen muhalefet eden yargıçların gelişmeci yorumun sınırlarıyla ilgili görüşlerine göre, Mahkemenin içtihatlarının gösterdiği üzere gelişmeci yorumun amacı, değişime eşlik etmek hatta istikamet vermektir; değişimi önceden tahmin edip uygulamak veya empoze etmek değildir. Bkz. Case of X and Others v. Austria, ECHR (Grand Chamber), Joint Partly Dissenting Opinion of Judges Casadevall, Ziemele, Kovler, Jočiene, Šikuta, De Gaetano, and Sicilianos of 19.02.2013, p. 23.

136 Forowicz, Magdalena: The Reception of International Law in the European Court of Human Rights, Oxford University Press, 2010, s. 12.

137 Forowicz, s. 12; Dzehtsiarou, s. 145.

138 Ziemele, s. 24. 
AİHM tarafından yeni andlaşma yükümlülükleri tespit etmek ya da yaratmak amacıyla kullanılmaktadır. Bir bakıma kural koyma yetkisinin uluslararası kural koyucu (AİHS'nin tarafları) ile Mahkeme arasında paylaşılması sonucunu doğuran bu uygulama, gerek çoğunluktan ayrılan bazı yargıçların gerek bazı hukukçuların eleştirisine yol açmaktadır. Bu çerçevede Mahkeme, kural koyma işlevi ile yorumlama işlevi arasındaki farkı gözetmeyip, yetkilerini sübjektif tercihlerine göre aşarak kural koyucu gibi hareket etmekle ve sözleşmeci devletlerin rızalarına yeterince saygı göstermemekle suçlanmaktadır. Öte yandan bazı hukukçular ise, özellikle devletlerin taraf olmakla tâbi olduğu insan hakları sözleşmelerinin ve onların denetim organlarının özel rollerine işaret ederek, AİHM'nin gelişmeci yorumunu meşru görmekte$\operatorname{dir}^{139}$. Esasen, ulusal veya uluslararası düzeyde olsun mahkemelerin ve yargıçların rolleri ve yetkilerinin kapsamı hakkındaki tartışmalar, oldukça eskiye dayanmaktadır ve hiçbir zaman da bitmeyecektir. Bu doğal görüş ayrılıkları, AİHM'nin ne şekilde hareket ederse etsin eleştirileceğini de göstermektedir ${ }^{140}$.

AİHM'nin salt gelişmeci yorumu değil Sözleşmedeki hakların geniş, etkili, özerk veya amaca uygun şekilde yorumlanması gerektiğine ilişkin yaklaşımı da aslında yukarıdakilere benzer tartışmalara konu olabilmekte$\operatorname{dir}^{141}$. Bütün bunların ötesinde Mahkemenin Sözleşmeyi yorumlarken etki-

139 Bkz. Vanneste, s. 246-252. Gelişmeci yorumun dayanağı ve kapsamıyla ilgili tartışmalar hakkında ayrica bkz. Senden, s. 152-154, 162.

140 Bu noktada Merrills, mesela önceden sakıncalı görülmeyen bir davranışın Avrupa'daki sonraki uygulamanın hangi noktasında kınanmayı gerektirecek bir davranış olarak değerlendirileceğine karar vermenin kolay olmadığını; Mahkemenin aşırı muhafazakâr davranması durumunda Sözleşmenin hedeflerini gerçekleştirmemekle, radikalizme yönelmesi durumundaysa yeni kurallar ihdas etmekle suçlanacağını belirtmektedir. Merrills, J. G.: The Development of International Law by the European Court of Human Rights, Manchester University Press, 1988, s. 157.

141 Mesela Mahkeme, Sözleşmenin 6. maddesinde açıça zikredilmeyen dava açma hakk1nın madde kapsamında olduğunu değerlendirirken, maddenin doğrudan lafzına, farklı dillerdeki versiyonlarına ve amacına odaklanmanın yanında, Sözleşmenin Başlangıcında ve Avrupa Konseyi Statüsünde yer alan hukukun üstünlüğü ilkesini ve dava açma hakkının hukukun genel ilkelerinden olduğunu da göz önünde bulundurmuştur. Bkz. Case of Golder v. the United Kingdom, ECHR (Plenary), Judgment of 21.02.1975, p. 28-36. Bir zamanlar gelenekçi görüşün en önemli temsilcilerinden sayılan Yargıç Fitzmaurice ise, diğer görüş ayrılıkları yanında, Sözleşmedeki bir boşluğu tamamlamanın devletlere düştüğünü, yargı organının kendisini sözleşme yapıcı yerine koyamayacağını belirtmiştir. Bkz. Case of Golder v. the United Kingdom, ECHR (Plenary), Separate Opinion of Judge Sir Gerald Fitzmaurice of 21.02.1975, p. 37. Benzer şekilde Yargıç Verdross da, Sözleşmenin 1. madde gereğince sadece 1. Bölümde belirtilen hakları güvence altına aldığına vurgu yaparak, bu hakları düzenleyen hükümlerin Mahkemenin yetkisinin 
lendiği birincil hususun Sözleşmenin ve kendisinin rolüyle ilgili kanaati olduğu belirtilmelidir ${ }^{142}$. Bununla birlikte Mahkemenin bu genel yaklaşımları, uyguladığı yorum ilke ve yöntemlerinin teorik temelleri hakkındaki kuşkuları gidermediği gibi, tutarlı ve öngörülebilir bir içtihat oluşturulmasını da sağlamamaktadır.

Konsensüs tekniğine dönülecek olursa, genellikle sözleşmeci devletlerin ulusal hukuklarındaki ve uluslararası hukuktaki gelişmelerin dikkate alınmasını sağlayan gelişmeci yaklaşımın temeline yönelik eleştirilerin

sınırını oluşturduğuna ve açıkça ifade edilen hakların çerçevesinin birtakım ipuçlarına dayanan bir yorumla genişletilemeyeceğine dikkat çekmiştir. Bkz. Case of Golder v. the United Kingdom, ECHR (Plenary), Separate Opinion of Judge Verdross of 21.02.1975.

142 Dijk/Hoof, s. 72-73. AİHM yerleşik içtihadında bu hususları çeşitli şekillerde vurgulamaktadır. Mesela Mahkemeye göre, tarafların üstlendikleri yükümlülükleri kısıtlayacak yorum değil, Sözleşmenin amaç ve hedeflerine ulaşmayı sağlayacak en uygun yorum seçilmelidir. Bkz. Case of Wemhoff v. Germany, ECHR (Chamber), Judgment of 27.06.1968, (Hüküm Gerekçesi) p. 8. AİHS, klasik andlaşmalardan farklı olarak, sözleşmeci devletler arasındaki karşılıklı yükümlülüklerden fazlasını içerir. Sözleşme karşılıklı yükümlülüklerin yanı sıra -Başlangıç Bölümündeki ifadeyle "müştereken uygulama"dan yararlanan- objektif yükümlülükler de yaratmaktadır. Bkz. Case of Ireland v. the United Kingdom, ECHR (Plenary), Judgment of 18.01.1978, p. 239. Sözleşme yorumlanırken, temel hakların müştereken uygulanması için yapılmış bir andlaşma olarak Sözleşmenin özel vasfına saygı gösterilmelidir. Bu açıdan tek tek insanların korunması için oluşturulan bir belge olan Sözleşmenin hedef ve amaçları, Sözleşme hükümlerini hakları pratik ve etkili (practical and effective) kılacak şekilde yorumlamayı ve uygulamayı gerektirir. Ayrıca güvence altına alınan hakların yorumlanması, demokratik bir toplumun ideal ve değerlerini korumak ve yükseltmek için tasarlanan bir belge olan Sözleşmenin genel ruhu ile de uyumlu olmalıdır. Bkz. Case of Soering v. the United Kingdom, ECHR (Plenary), Judgment of 07.07.1989, p. 87. Sözleşme, hakları teorik veya hayalî (theoretical or illusory) şekilde değil, pratik ve etkili bir biçimde güvence altına almayı amaçlamaktadır. Bkz. Case of Cruz Varas and Others v. Sweden, ECHR (Plenary), Judgment of 20.03.1991, p. 99; Case of Glor v. Switzerland, p. 76. Dahas1, AİHM kararlarının sadece Mahkemenin önündeki olayların çözümüne değil, aynı zamanda Sözleşmede yer alan kuralların açıklığa kavuşturulması, korunması ve geliştirilmesine de hizmet edip, Sözleşmenin 19. maddesinde belirtildiği gibi sözleşmeci devletlerin üstlendikleri yükümlülüklere uymalarını sağladığı vurgulanmaktadır. Bkz. Case of Ireland v. the United Kingdom, p. 154. Yine, Sözleşmeyle kurulan sistemin başlıca amacının bireysel durumlara çözümler getirmek olmakla birlikte, sistemin bir misyonunun da, kamu düzenine ilişkin meseleleri ortak menfaate göre kararlaştırmak ve böylece insan haklarının korunmasına ilişkin genel standartları yükseltmek ve sözleşmeci devletlerde insan hakları hukukunu yaygınlaştırmak olduğu belirtilmektedir. Bkz. Case of Rantsev v. Cyprus and Russia, p. 197. Bunlara ilaveten Mahkeme, Sözleşmeyi insan hakları alanında "Avrupa kamu düzeninin anayasal belgesi" olarak nitelendirmektedir. Bkz. Case of Loizidou v. Turkey (Preliminary Objections), ECHR (Chamber), Judgment of 23.03.1995, p. 75 . 
burada da geçerli olduğu belirtilmelidir ${ }^{143}$. Bu sebeple söz konusu tekniğin meşruiyeti bakımından ve tutarlı bir şekilde uygulanması için birtakım dayanaklar aranmaktadır.

Nisbeten sade bir görüşe göre, Sözleşmenin Başlangıç Bölümündeki ifadeler konsensüs tekniği için dayanak teşkil edebilir ${ }^{144}$. Zira burada belirtildiği üzere, “... korunmast ... insan hakları konusunda ortak bir anlayış ve ortaklaşa saygı esasına bağlı olan bu temel özgürlüklere derin bağlllıklarını bir kez daha tekrarlayarak; ayn inancı taşıyan ve siyasal gelenekler, idealler, özgürlüklere saygl ve hukukun üstünlüğ̈̈ konularında ortak bir mirası paylaşan Avrupa devletlerinin hükümetleri sıfatıyla ... aşağıdaki konularda anlaşmışlardır."

Daha kapsamlı değerlendirmeler yapan Ziemele'ye göre, uygulamadaki kusur ve noksanlıklar ile eleștiriler göz önünde bulundurulduğunda, Avrupa konsensüsü tekniğinin uluslararası hukukun kaynakları ve andlaşmaların yorumlanmasına ilişkin genel kurallar çerçevesinde açıklanmasının önemi ortaya çıkar. Konunun genel uluslararası hukuk perspektifinden pek değerlendirilmediğini tespit eden yazar bu bağlamda "Bir andlaşma olan AİHS karşısında konsensüsün hukukî değeri nedir?”; "Konsensüs, bölgesel örf ve âdetle karşılaştırılabilir mi veya daha genel olarak devletlerin yeni bir rızasını mı ifade eder?" sorularını sormaktadır ${ }^{145}$. Genel olarak konsensüsün uluslararası hukuka dayandırılmasını savunan yazarın daha spesifik görüşleri aşağıda aktarılacaktır.

AİHM'nin genel uygulamasiyla birlikte kanaatini de aktaran Vanneste'ye göre, meşruiyet sorunları daha çok hukukî gerekçelendirmedeki şeffaflık ve tutarlılık eksikliğinden kaynaklanmaktadır. Bununla birlikte,

143 Konsensüs tekniğinin esasına yönelik, çok farklı istikametten bir başka eleştiri de vardır. $\mathrm{Bu}$ görüşe göre, insan hakları esas itibarıyla çoğunluk karşıtı (anti-majoritarian), yani bireyi çoğunluğun tahakkümüne karşı koruyucu nitelikte olduğu için, çoğunluğun yaklaşımına dayanarak insan haklarının yorumlanıp, uygulanması meşru değildir. Ancak belirtmek gerekir ki, çoğu kez Sözleşmedeki hakların kapsamını genişletmek için kullanılan Avrupa konsensüsünün insan haklarının korunması bakımından tehlike arz ettiğini öne sürmek güçtür. Dahas1, nisbeten objektif bir kriter olan Avrupa konsensüsüne alternatif olarak sunulan ahlakî değerlere göre karar vermek çok daha sorunlu görünmektedir. Bkz. Dzehtsiarou, s. 115-117, 142. Bu bakımdan araştırılması gereken esas sorun da, Sözleşmedeki hakların Avrupa konsensüsüne dayanarak içtihat yoluyla geliştirilmesinin meşru olup olmadığıdır.

144 Bkz. Forowicz, s. 9; Senden, s. 136, 142. Sözleşmenin gelişmeci bir biçimde yorumlanması için Başlangıç Bölümünün bir dayanak sağlayabildiği hakkında ayrıca bkz. Schabas, s. 48.

145 Ziemele, s. 24-25. 
gelişmeci yorum ilkesiyle yeni Sözleşme yükümlülüklerinin tespiti esasen uluslararası örf ve âdet kurallarının tespitine benzediği için, bunun devlet uygulamalarına dayanan konsensüsün hukukî ilgisi ortaya koyularak, ikna edici bir şekilde yapılması gerekir ${ }^{146}$. Bu bağlamda yazar, sözleşmeci devletlerin uygulamalarının aynı tip ve yaygın olmasının konsensüsün varllğını ispatlayacağını, daha doğrusu AİHM'nin karşılaştığı sorunla ilgili uygulamanın bu özellikleri ne kadar çok taşırsa, konsensüsün yokluğuna karar vermenin o kadar zorlaşacağını belirtmektedir. Dahası, Mahkeme -Sözleşme metnini, davalı devletin tutumunu, uluslararası kuralları ve diğer hususları göz önünde bulundurarak- bu konsensüsün gelişmeci yorumu gerektirdiğine ilişkin genel inancı da (opinio juris) tespit etmelidir ${ }^{147}$. Bu son unsurla ilgili olarak yazar, açık ve sağlam (clear/firm) bir konsensüsün prensip olarak yeni bir yorumun gerektiğine ilişkin inancın bulunduğunu göstereceğini; öte yandan gelişmekte olan (emerging) konsensüsün ancak başka delillerle desteklenirse bu sonucu vereceğini; konsensüsün yokluğunun ise -kural metni açı değilse- genel olarak devlete takdir marji verilmesini gerektireceğini belirtmektedir ${ }^{148}$.

Dzehtsiarou ise, Avrupa konsensüsüne başvurulmasının karar verme sürecine ve kararlara bizâtihi meşruiyet ve hukukîlik sağladığını savunmaktadır. Zira bir genel ilke veya daha spesifik bir kural üzerinde sözleşmeci devletlerin güncellenmiş rızası olarak açıklanabilecek Avrupa konsensüsü, Mahkemenin Sözleşmeyi aslına tamamen sadık bir şekilde (orijinal rızaya uygun olarak) yorumlamamasına yönelik eleştirileri önemli ölçüde bertaraf eder. Öte yandan Avrupa konsensüsü uluslararası hukukun herkesçe kabul edilmiş kaynaklarından örf ve âdet ile hukukun genel ilkeleri çerçevesinde açıklanabileceği için, konsensüs tekniğini doğrulanmış verilere dayanarak, uygun ve tutarlı bir şekilde uygulaması durumunda Mahkeme keyfî hareket ettiği yönündeki eleştirilerden kurtulabilir ve meşruiyetini arttırabilirr ${ }^{149}$. Yine

146 Bkz. Vanneste, s. 252-253, 293.

147 Vanneste, s. 264.

148 Bkz. Vanneste, s. 278-292.

149 Bkz. Dzehtsiarou, s. 149, 158-160, 175-176. Bu bağlamda yazara göre Avrupa konsensüsü, devletler açısından kabul edilebilir çerçeve içinde kalıp meşruiyet duvarını aşmamayı, ama aynı zamanda Avrupa'da gelişen fikirleri hesaba katmayı sağlayabilen bir araçtır. Dzehtsiarou, s. 155. Yakın bir görüsse göre de Mahkeme, Sözleşmenin dinamik vasfını gözeterek bir karar verirken, hukuk politikasındaki değişikliklerin Avrupa devletleri arasında Sözleşmenin anlamını etkileyecek kadar geniş bir kabul görüp görmediğini esas almalıdır. Uygulamada da Mahkeme genellikle, dayanaksız şekilde yeni bir yaklaşım ortaya koymak yerine, devlet uygulamalarını göz önünde bulunduran dikkatli bir tutum sergilemektedir. Bu bağlamda Mahkemenin Avrupa konsensüsüne 
de yazar, gerek uluslararası örf ve âdetin gerek hukukun genel ilkelerinin tespiti aynı Avrupa konsensüsünün saptanmasında olduğu gibi karşılaştırmalı verilere dayansa da, Avrupa konsensüsü olarak yorumlanan bir uygulamanın örf ve âdetin geleneksel unsurlarını her zaman taşımadığına ve genel ilkelerin ya da ilkeler düzeyinde konsensüsün olayın çözümü için kesin ve spesifik kurallar sağlamayabildiğine dikkat çekmektedir ${ }^{150}$.

\section{B. AİHM'nin Uygulaması}

AİHM'nin genel uygulaması, konsensüs tekniğinin uluslararası hukuk çerçevesindeki hukukî zeminini ortaya koyacak kadar kapsamlı, tutarlı ve açık değildir. Yine de bazı kararlarda bu tekniğin dayanağı hakkında birtakım emareler bulunmaktadır.

AİHM, Golder v. Birleşik Krallık Davasında Andlaşmalar Hukukuna Dair Viyana Sözleşmesinin andlaşmaların yorumlanmasına iliş̧in uluslararası hukukun genel ilkelerini düzenleyen m. 31-33 hükümlerinin kendisine rehberlik ettiğini belirtmiştir ${ }^{151}$. Viyana Sözleşmesi m. 31/3 hükmü, bir andlaşmanın kabulünden sonraki anlaşma ve uygulama ile uluslararası hukukun (önceki veya sonraki) ilgili diğer kurallarının andlaşmanın yorumlanmasında göz önünde bulundurulmasına ilişkin esasları düzenlemektedir. Buna göre,

"Andlaşmanın bütünü ile birlikte aşağıdakiler de dikkate alınır: a) Taraflar arasında andlaşmanın yorumu veya hükümlerinin uygulanmast ile ilgili olarak yapılan daha sonraki herhangi bir anlaşma, b) Tarafların andlaşmanın yorumu konusundaki mutabakatını tespit eden, andlaşmanın uygulanmast ile ilgili daha sonraki herhangi bir uygulamast, c) Uluslararası hukukun taraflar arasındaki iliş̧kilerde tatbiki kabil ilgili herhangi bir kuralı."

Avrupa konsensüsü, Sözleşmenin gelişmeci yorumunun bir parçasını teşkil ettiğine göre, bu fikra hükmündeki unsurlardan herhangi biri olarak veya onlarla ilgili görülebilir ${ }^{152}$. AİHM'nin bazı kararları da bunu teyit eder

dayanması, muhtemelen kabul görmüş insan hakları standartları yönünde sonuç doğuracağı için, genel olarak meşru görünmektedir. Harris/O'Boyle/Bates/Buckley, s. 8-9.

150 Bkz. Dzehtsiarou, s. 16, 161-163. AİHM'nin günün koşullarını genellikle devletlerin değişen uygulamalarına referansla tespit etmesinin, örf ve âdetin tespitindeki yaklaşıma bir ölçüde benzediği hakkında ayrıca bkz. Higgins, Rosalyn: "Time and the Law: International Perspectives on an Old Problem", International and Comparative Law Quarterly, 1997, Vol. 46, s. 517.

151 Bkz. Case of Golder v. the United Kingdom, p. 29. Sözleşmenin 31. maddesi genel yorum kuralları, 32. madde tamamlayıcı yorum araçları ve 33. madde iki veya daha fazla dilde düzenlenmiş andlaşmaların yorumu hakkındadır.

152 Ziemele, s. 26. 
niteliktedir. Mahkeme, gerek içsel gerek dışsal karşılaştırmalı yorum araçlarını kullanırken zaman zaman bu fıkranın bentlerine açıkça veya üstü kapalı şekilde atıf yapmaktadır.

Mesela Mahkemeye göre, ölüm cezasının kaldırılması şeklindeki sonraki genel uygulama, sözleşmeci devletlerin 2. maddedeki istisnayı kaldırmak konusunda bir anlaşması olarak değerlendirilebilir. Ancak ilgili 6 . Protokolün varlığı, sözleşmeci devletlerin bu konuda yeni bir yükümlülük getirmek için metnin normal yoldan değiştirilmesi yöntemini tercih ettiğini göstermektedir ${ }^{153}$.

Mahkeme, Cruz Varas ve Diğerleri v. İsveç Davasında, bu sefer Viyana Sözleşmesi m. 31/3(b)'yi zikrederek, sonraki uygulamanın Sözleşmenin bir hükmünün yorumlanmasıyla ilgili olarak sözleşmeci devletler arasındaki uzlaşıyı tespit eden bir unsur olarak kabul edilebileceğini; ancak Sözleşmede yer almayan hak ve yükümlülükleri ihdas etmek için kullanılamayacağını belirtmiştir ${ }^{154}$. Sözleşmeci devletlerin Komisyonun İçtüzüğü uyarınca verdiği geçici tedbir kararlarına genellikle uygun davranmasının, bu kararların bağlayıcı olduğu inancına dayandığı söylenemez; bu uygulama daha çok iyiniyetli bir işbirliğini gösterir. Sonuç olarak Mahkeme, geçici tedbirin uygulanmamasının, bireysel başvuru hakkının etkili bir şekilde kullanılmasının engellenmemesi hakkını öngören 25. (şimdiki 34.) maddeyi ihlal etmediğine karar vermiştir ${ }^{155}$. Görüldüğü üzere burada sözleşmeci devletlerin sonraki genel uygulaması, yükümlülük doğuracak veya kararın gerekçesi olacak şekilde yorumlanmamakla birlikte, Sözleşmenin yorumlanmasında göz önünde bulundurulacak etkenlerden biri olarak teyit edilmiştir. Burada dikkat çeken bir diğer husus da, Mahkemenin sonraki uygulamanın hukukî bir zorunluluk bilinciyle gelişmediğine işaret etmiş olmasıdır ${ }^{156}$.

153 Bkz. Case of Soering v. the United Kingdom, p. 103.

154 Bu noktada varılan sonuç, Soering v. Birleşik Krallık Davasındakinden farklıdır. Mahkemenin Cruz Varas ve Diğerleri v. İsveç Davasındaki tutumunun meşruiyet sorunlarına yol açmama kaygısından kaynaklandığı hakkında bkz. Forowicz, s. 42.

155 Bkz. Case of Cruz Varas and Others v. Sweden, p. 100. Ancak daha sonra Mahkeme, Mamatkulov ve Askarov v. Türkiye Davasında, Sözleşmenin kurduğu sistemi göz önünde bulundurmanın yanında, Uluslararası Adalet Divanı Statüsüne, Divanın içtihadına ve öteki uluslararası denetim organlarının düzenlemelerine de gönderme yaparak, geçici tedbir kararlarının davalı devlet için bağlayıcı olduğuna hükmetmiştir. Uluslararası hukukun diğer kaynaklarını dikkate alırken AİHM'nin hareket noktalarından biri, Viyana Sözleşmesinin m. 31/3(c) hükmü olmuştur. Bkz. Case of Mamatkulov and Askarov v. Turkey, ECHR (Grand Chamber), Judgment of 04.02.2005, p. 39-53, 111 vd.

156 Vanneste, Mahkemenin sözleşmeci devletlerin geçici tedbirlere uymayı bir yükümlülük olarak görüp görmedikleri hakkında gerçek bir araştırma yapmadığını belirtmektedir. Vanneste, s. 284 
Loizidou v. Türkiye Davasında ilk itirazları incelerken Mahkeme, m. 31/3(b)'yi de zikrederek, bireysel başvuru hakkıyla ilgili 25. ve Mahkemenin yarg1 yetkisinin tanınmasıyla ilgili 46. maddelerin ülkesel veya esaslı kısıtlamalara izin vermediğini, bunun taraf devletler arasında genel bir anlaşma bulunduğunu gösteren tutarlı uygulamayla teyit edildiğini belirtmiştir ${ }^{157}$.

Mahkeme, Hassan v. Birleşik Krallık Davasında, Irak'in 2003'teki işgali sırasında Birleşik Krallık güçleri tarafından güvenliğe tehdit teşkil edebileceği düşüncesiyle yakalanıp, tutulan (internment) ve sorgusunun ardından serbest bırakılmakla birlikte, bir süre sonra ölü bulunan bir kişinin diğerleri yanında AİHS m. 5'teki haklarının ihlal edilip edilmediğini incelerken, Viyana Sözleşmesi m. 31/3(b)'ye gönderme yaparak, sözleşmeci devletlerin sonraki tutarlı uygulamasının Sözleşmenin yorumlanması hatta değiştirilmesi yönünde bir anlaşma teşkil edebileceğini belirtmiştir ${ }^{158}$. Bunun ardından Mahkeme, sözleşmeci devletlerin uluslararası silahlı çatışmalar sırasında III. ve IV. Cenevre Sözleşmelerine dayanarak kişileri tutabilmek için 15. maddedeki derogasyon hakkını kullanmak (5. maddedeki yükümlülüklerini azaltmak) yönünde bir uygulamasının olmadığını tespit ederek, bu hak kullanılmamış olsa da uluslararası silahlı çatışmalarda kişilerin bu şekilde tutulmasının 5. maddedeki özgürlükten mahrum bırakma sebeplerinden sayılabileceğini belirtmiştir. Bununla birlikte bu durumlarda da Sözleşmenin sağladığı güvenceler uygulanmaya devam edecektir ${ }^{159}$.

Her ne kadar yukarıdaki davada olduğu gibi, Avrupa konsensüsü yerine sadece Viyana Sözleşmesi m. 31/3(b)'ye gönderme yapılmış olsa da, Mahkemenin sonraki uygulamayı zikretmesi de konsensüs arayışının bir parçası olarak görülmelidir ${ }^{160}$.

AİHM, Demir ve Baykara v. Türkiye Davasına ilişkin kararında ise, kullandığı karşılaştırmalı yorum araçlarıyla ilgili esaslar hakkında diğerle-

157 Bkz. Case of Loizidou v. Turkey (Preliminary Objections), p. 73, 79-80, 82.

158 Bu noktada varılan sonuç, Soering v. Birleşik Krallık Davasındakiyle aynıdır.

159 Bkz. Case of Hassan v. the United Kingdom, ECHR (Grand Chamber) Judgment of 16.09.2014, p. 101, 104. Mahkemenin özellikle Sözleşmenin ülke dış1 uygulanabilirliğini ve insan hakları hukuku ile insancıl hukuk arasındaki ilişkiyi ortaya koyduğu bu kararı hakkında bir değerlendirme ve ayrıca söz edilen sonraki uygulamanın Mahkemenin vardığı sonucu desteklemeyebileceği hususunda bir eleştiri için bkz. HillCawthorne, Lawrence: "The Grand Chamber Judgment in Hassan v. UK”, EJIL: Talk!, 16.09.2014. Erişim: https://www.ejiltalk.org/the-grand-chamber-judgment-in-hassan-v$\mathrm{uk} /$.

160 Ziemele, Mahkemenin konsensüs ile devletlerin sonraki uygulaması arasında bir ayrıma gittiğinin düşünülebileceğini, her ikisiyle kastedilen aynı şeyse Mahkeme tarafindan buna açıklık getirilmesinin faydalı olacağını belirtmektedir. Ziemele, s. 32, 36. 
rinden daha ayrıntılı açıklamalar yapmıştır. Burada, daha geleneksel yorum araçlarının Sözleşmenin bir hükmünün kapsamının yeterli şekilde açıklığa kavuşturulmasına imkân vermediği takdirde, devletlerin büyük çoğunluğunun kabul ettiği kural ve ilkelerden oluşan uluslararası hukukun veya Avrupa devletlerinin ulusal hukuklarının ortak standartlarının Mahkemenin göz ardı edemeyeceği bir gerçekliği yansıttığı belirtilmiştir ${ }^{161}$. Bunun yanında Mahkeme, Sözleşmeyi ve onun sözleşmeci devletlere yüklediği yükümlülükleri yorumlarken muhtelif andlaşmaları göz önünde bulundurduğunu, uygar uluslarca kabul edilmiş hukukun genel ilkelerini taraflar arasındaki ilişkilere uygulanabilir olan uluslararası hukuk kuralları arasında gördüğünü ${ }^{162}$, diğerleri yanında Avrupa Konseyi organlarının soft law sayllabilecek tavsiye niteliğindeki kararlarını da dikkate aldığını ifade etmiştir ${ }^{163}$.

Sonuç olarak Mahkeme, Sözleşmedeki terim ve kavramları tanımlarken Sözleşme dışındaki uluslararası hukuk belgelerini, yetkili organların bu belgelerle ilgili yorumlarını ve Avrupa devletlerinin ortak değerlerini yansıtan uygulamalarını dikkate alabilir ve almalıdır. "Uluslararası belgelerden ve sözleşmeci devletlerin uygulamalarından kaynaklanan konsensüs", Sözleşme hükümlerini yorumlarken Mahkeme için bir etken olabilir ${ }^{164}$. Bu bağlamda, davalı devletin davanın konusu bakımından uygulanabilir olan belgelerin tümünü onaylamış olması da gerekmez. Mahkeme için, ilgili uluslararası belgelerin uluslararası hukukta veya Avrupa Konseyi üyelerinin çoğunun hukukunda uygulanan norm ve ilkelerde devam etmekte olan gelişimi (continuous evolution) ifade etmesi ve belirli bir konuda modern toplumlarda

161 Bkz. Case of Demir and Baykara v. Turkey, p. 76. Mahkeme, bu tespitinden önce, Viyana Sözleşmesinin yorum kurallarının kendisine rehberlik ettiğini; insan haklarının korunmasına ilişkin bir sistem kuran Sözleşmenin hakları etkili kılacak şekilde yorumlanmas1 gerektiğini; Viyana Sözleşmesi m. 31/3(c)'ye gönderme yaparak Sözleşme hükümlerini yorumlarken sadece Sözleşme hükümlerini referans almadığını ve sözleşmeci devletler arasındaki ilişkilere uygulanabilir ilgili uluslararası hukuk kural ve ilkelerini dikkate alması gerektiğini; ayrıca günün koşulları 1şığında yorumlanması gereken Sözleşmenin yaşayan bir belge olduğunu ve ulusal ve uluslararası hukukun gelişmekte olan normlarını dikkate aldığını belirtmiştir. Bkz. Case of Demir and Baykara v. Turkey, p. 65-68.

162 Mahkeme, daha önce de, taraflar arasındaki ilişkilerde uygulanabilir olan ilgili uluslararası hukuk kurallarının, uygar uluslarca tanınmış hukukun genel ilkelerini içerdiğini belirtmiştir. Burada, Avrupa Konseyi Danışma Meclisi Hukuk Komitesinin 1950'de Komisyonun ve Mahkemenin görevlerini yerine getirirken bu tür ilkeleri uygulamasının gerekeceğini öngördüğü ve AİHS'ye bu kapsamda spesifik bir madde eklemeyi gereksiz bulduğu da hatırlatılmıştır. Bkz. Case of Golder v. the United Kingdom, p. 35.

163 Bkz. Case of Demir and Baykara v. Turkey, p. 69-75.

164 Bkz. Case of Demir and Baykara v. Turkey, p. 85. 
ortak bir payda olduğunu göstermesi yeterlidir ${ }^{165}$. Görüldüğü üzere Mahkeme, Viyana Sözleşmesi m. 31/3(c)'yi zikrederek uluslararası hukukun ilgili diğer kurallarını ve m. 31/3(b)'yi açıçca belirtmeden devletlerin sonraki uygulamasını Sözleşmenin yorumlanmasında göz önünde bulunduracağını belirtmektedir. Ayrıca Mahkeme, karşılaştırmalı yorumunu gelişmeci yorum ilkesine dayandırdığını da ortaya koymaktadır ${ }^{166}$.

AİHM, kararlarının çoğunda ise konsensüs tekniğini Viyana Sözleşmesinin andlaşmaların yorumlanmasına ilişkin hükümlerine atıf yapmadan uygulamaktadır. Bu noktada konsensüsün gerek dayanağı gerek etkisi bak1mından önemli özellikler gösteren, daha önce bahsettiğimiz $A, B$ ve $C$ v. Irlanda Davasına ilişkin karara odaklanmak faydalı olacaktır. Bu kararda Mahkeme, konsensüsün varlığının, Tyrer v. Birleşik Krallık Davasından beri, Sözleşmedeki güvencelerin geliştirilmesinde önemli bir rol oynadığını, yaşayan belge yaklaşımıyla bağlantılı olarak konsensüse Sözleşmenin dinamik bir şekilde yorumlanmasını gerekçelendirmek için başvurduğunu ifade etmiştir $^{167}$. Kararda Mahkemenin özel bir hukukî dayanak aramadan Avrupa konsensüsünü özerk bir anlamda kullandığı görülmektedir. Bu tutum, andlaşmaların yorumuna ilişkin genel kuralların bazı katı unsurlarının insan haklarının etkili biçimde korunması amacına hizmet etmeyebileceği endişesini yansıtmaktadır. Ancak Ziemele, bunlara daha açık bir şekilde dayanmanın gerektiği ve yorum kurallarının da gelişmeci yorumun kullanılmasını engellemediği görüşündedir ${ }^{168}$.

Öte yandan bu karar, konuyla ilgili bir Avrupa konsensüsü olsa da, bunun farklı uygulaması olan devletlere otomatik olarak spesifik bir yükümlülük yüklemeyeceğini, buna uymamanın da tek başına Sözleşmenin ihlali anlamına gelmeyeceğini ortaya koymaktadır. Doğal olarak bu durum, konsensüsün rolünü ve normatif etkisini sorgulanır kılıp, yaklaşım tutarsızlığı eleştirilerine yol açmaktadır. Ancak, Ziemele'ye göre somut olay bakımından bunun birtakım izahları olabilir. Öncelikle bu davada incelenen 8. mad-

165 Bkz. Case of Demir and Baykara v. Turkey, p. 86. Bu açıklamalar özellikle Türkiye'nin itirazlarına cevap niteliğindedir. Türkiye'ye göre, AİHM yorum yoluyla Sözleşmede öngörülmemiş olan (yeni) yükümlülükler yaratamaz. AİHM gerektiğinde taraflar arasındaki ilişkilere uygulanabilir uluslararası hukukun ilgili kurallarını daima dikkate almaktadır; ancak bu yaklaşım Viyana Sözleşmesi m. 31/3'teki kriterlere uyulduğunda ve özellikle ilgili devletin bağlı olduğu anlaşmalar dikkate alındığında meşru olacaktır. Bkz. Case of Demir and Baykara v. Turkey, p. 61.

166 Senden, s. 244.

167 Bkz. Case of $A, B$ and $C$ v. Ireland, p. 234.

168 Ziemele, s. 36, 39. 
denin -Sözleşmenin mutlak haklar öngören maddelerinden farklı olarakdevletlerin uygularken geniş bir takdir marjından yararlanabildiği açık uçlu haklar getirdiği belirtilmelidir. Yine, Mahkemenin İrlanda'daki kısıtlamanın çeşitli referandumlar neticesinde kabul edilmiş olduğunu da göz önünde bulundurduğu görülmektedir. Yazara göre Mahkeme, davalı devletin ilgili madde gereğince özel hayatın ve toplumun değerlerinin korunmasını dengelemede zaten sahip olduğu takdir marjı ile birlikte, Viyana Sözleşmesi m. 31/3(c) gereğince bölgesel örf ve âdete de dayanmış olsayd1, bu, bir bakıma sürekli itiraz eden bir devlet konumundaki İrlanda'nın farklı uygulamasını sürdürmesine izin verilmesinin çok daha iyi bir gerekçesi olabilirdi ${ }^{169}$.

\section{Değerlendirmemiz}

Öncelikle belirtmek gerekir ki, gerek sözleşmeci devletlerin yükümlülükleri gerek AİHM'nin yarg1 yetkisi konu bakımından AİHS'nin düzenlediği hak ve özgürlüklerle sınırlıdır ${ }^{170}$. Her ne kadar Sözleşmenin hangi haklar bakımından koruma sağladığı açık olsa da, Sözleşmede ayrıntılı bir biçimde düzenlenmeyen bu hakların ne ifade ettiği ve kapsamı tam olarak belirli değildir. Dolayısıyla Mahkemenin kendisine sunulan olaylar çerçevesinde Sözleşmeyi yorumlaması olağan bir iştir. Elbette bu faaliyetin belirli esaslar ve sınırlar çerçevesinde icrası gerekir.

Uluslararası hukukun kaynakları ve yorum kuralları çerçevesinde uygulanmasının konsensüs tekniğinin meşruiyetini sağlamlaştıracağ 1 şüphesizdir. Bununla birlikte, Sözleşmenin ve kendisinin rolünü her zaman için diğer dayanaklardan üstün tutan Mahkemenin konsensüs tekniğine başvurmak için başlıca gerekçesinin de içtihatlarıyla benimsediği gelişmeci yorum ilkesi olduğu görülmektedir. Mahkemenin birçok kez vurguladığı üzere, Sözleşme günün koşulları ve demokratik devletlerde hâkim olan kavramlar ışığında yorumlanması gereken yaşayan bir belgedir ${ }^{171}$. Sözleşmenin yaşayan belge niteliğiyle bağlantılı olarak, Sözleşme hükümlerinin yorumlanmasında ulusal

169 Bkz. Ziemele, s. 37-39.

170 Sözleşmeci devletler Sözleşmede belirtilen hak ve özgürlükleri sağlama yükümlülüğündedir (m. 1). Mahkeme Sözleşmeyle yüklenen yükümlülüklere uyulmasını sağlamak hususunda yetkilidir (m. 19). Mahkemenin yarg1 yetkisi Sözleşmenin yorumu ve uygulanmasına ilişkin olup, belirli koşullarla kendisine sunulan tüm sorunları kapsar (m. 32). Sözleşmede düzenlenen haklarının sözleşmeci devletlerden biri tarafından ihlal edilmesinden dolayı mağdur olduğunu öne süren her gerçek kişi, hükümet dışı kuruluş veya kişi grupları Mahkemeye başvurabilir (m. 34).

171 Bkz. Case of Van der Mussele v. Belgium, p. 32; Case of S.A. Dangeville v. France, ECHR (Second Section), Judgment of 16.04.2002 (final 16.07.2002), p. 47; Case of Stummer v. Austria, ECHR (Grand Chamber), Judgment of 07.07.2011, p. 118. 
ve uluslararası hukukun ortaya çıkan normları dikkate alınır ${ }^{172}$. Sözleşme yaşayan bir belge olduğu için, belirli bir önlemin Sözleşme bakımından kabul edilebilir olup olmadığına karar verirken, üye devletler arasında hâkim olan standartları göz önünde bulundurmak meşrudur ${ }^{173}$.

Ne var ki, AİHM'nin konsensüs tekniğine bizzat kendisinin dayanağ 1 tartışmalı olan gelişmeci yorum ilkesine dayanarak başvurması, meşruiyet sorunlarını ortadan kaldırmamaktadır. Mesele Avrupa konsensüsünün tespitindeki kusur veya tutarsızlıklarla sınırlı değildir. Neden farklı uygulaması olan bir sözleşmeci devletin Avrupa konsensüsüne (çoğunluğun uygulamasina) uymak zorunda olduğu hususunun ${ }^{174}$ uluslararası hukukun kaynakları ve yorum kuralları çerçevesinde tam bir açıklaması yoktur. Şüphesiz uluslararası hukuk, uluslararası mahkemelere hukukun zaman içindeki değişimini belirli bir şekilde dikkate alma yetkisi tanır. Ancak, buna imkân tanıyan yorum kuralları ile örf ve âdetin pozitif uluslararası hukuktaki kapsamlarının/tanımının AİHM'nin başvurduğu Avrupa konsensüsüne göre oldukça dar olduğu belirtilmelidir.

$\mathrm{Bu}$ bağlamda belirtmek gerekir ki, Mahkeme Viyana Sözleşmesi m. 31/3'teki yorum araçlarını maddedeki kayıtları pek dikkate almadan belirli bir esneklik içinde uygulamaktadır. Mesela sonraki ortak uygulamanın spesifik olarak "andlaşmanın uygulanması ile ilgili" olup olmadığına fazla önem verilmemektedir ${ }^{175}$. Yine, Uluslararası Hukuk Komisyonunun "Andlaşmaların Yorumlanması Bakımından Sonraki Anlaşmalar ve Sonraki Uygulama Hakkında Sonuç Bildirgesi Taslağı"nın şerhinde belirtildiği üzere, AİHM'nin yaşayan belge yaklaşımını ve gelişmeci yorumu benimsediği kararlar sözleşmeci devletlerin sonraki uygulamalarının değişik biçimleri çerçevesinde gerekçelendirilse de, Mahkeme sonraki uygulamanın "tarafların andlaşmanın yorumu konusundaki mutabakatı"nı tespit etmesi şartını aramamaktadır ${ }^{176}$. Bir değerlendirmeye göre de m. 31/3, gelişmeci yorum ve

172 Bkz. Case of Demir and Baykara v. Turkey, p. 68.

173 Bkz. Case of T. v. the United Kingdom, p. 70.

174 Bu noktada Dzehtsiarou, konsensüse değil Sözleşmeye uymamanın bir ihlal olarak kabul edileceğini belirtmektedir. Dzehtsiarou, s. 153. Kanımızca, konsensüs tekniğinin Sözleşmedeki hakların anlamları ile yükümlülüklerin kapsam ve içeriğini ortaya çıkarmak için uygulanan bir yöntem olduğuna dikkat edilirse, bu görüşün yerinde olmadığı açıktır.

175 Ziemele, s. 28.

176 Bkz. "Draft Conclusions on Subsequent Agreements and Subsequent Practice in relation to the Interpretation of Treaties, with Commentaries", Yearbook of the ILC, 2018, Vol. 2, Part 2, s. 68. 
konsensüs tekniği için ancak sınırlı bir dayanak sağlayabilir. Zira maddedeki kavramların ne şekilde tanımlanacağı ve özellikle bir sonraki anlaşma veya uygulamadan söz edebilmek için bütün sözleşmeci devletlerin rızasının gerekip gerekmediği açık değildir; dahası farklı uygulaması olan devletin bu tutumunun bir itiraz niteliğinde olduğu da öne sürülebilir ${ }^{177}$.

Öte yandan AİHM, Avrupa konsensüsün varlığını tespit ederken, örf ve âdetin varlığı için gerekli unsurları da bire bir gözetmeyip ${ }^{178}$, genellikle daha esnek davranmaktadır. Ayrıca, Avrupa konsensüsüne dava konusu hukuk veya uygulamanın genellikle kabul edilen standartlardan farklı olduğu durumlarda başvurulduğu göz önünde bulundurulursa ${ }^{179}$, Avrupa konsensüsüne örf ve âdete dayanarak başvurulmasının konsensüs tekniğini neredeyse her zaman işlevsiz kılacağı açıktır. Zira böyle bir durumda davalı devlet sürekli itiraz eden devlet olarak, konsensüsün veya örf ve âdetin dışında kalma hakkını çoğu kez koruyacaktır. Bu “tehlike", Mahkemenin Avrupa konsensüsünü örf ve âdet çerçevesinde izah etmemesinin temel sebebi olarak görülebilir.

Bunların yanında, Avrupa konsensüsünün uygar uluslarca kabul edilmiş hukukun genel ilkeleriyle (the general principles of law recognized by civilized nations ${ }^{180}$ ilișkili olduğu da göz ardı edilemez. Ancak bunlar da, Mahkemenin karşılaştı̆̆ 1 konuya uygulanabilir somut kuralları zaman zaman sağlamadığı için, konsensüs tekniğinin dayanağını tam olarak açıklamamak-

177 Bkz. Senden, s. 150-151.

178 Uluslararası Adalet Divanı Statüsünün 38. maddesi Divanın uyuşmazlıkları ele alırken uygulayacağı kaynaklar arasında "hukuk olarak kabul edilen genel bir uygulamanın kanıtı olarak uluslararası örf ve âdeti" de (international custom, as evidence of a general practice accepted as law) zikretmektedir. UAD Statüsü için bkz. https://www.icjcij.org/en/statute. Bu tarif, uluslararası örf ve âdetin hem maddî unsuruna (genel, istikrarlı bir uygulama) hem de manevî unsuruna (uygulamanın hukukî zorunluluk teşkil ettiği kanaati; opinio juris sive necessitatis) işaret etmektedir. Ayrıntılı bilgi için bkz. Pazarcı, Hüseyin: Uluslararası Hukuk Dersleri, 1. Kitap, Gözden Geçirilmiş 12. Bask1, Turhan Kitabevi, 2014, s. 223-236; Aybay, Rona/Oral, Elif: Kamusal Uluslararas1 Hukuk, İstanbul Bilgi Üniversitesi Yayınları, 2016, s. 122-127; Sur, Melda: Uluslararas1 Hukukun Esasları, Gözden Geçirilmiş 12. Baskı, Beta, 2018, s. 81-85.

179 Dzehtsiarou, s. 152.

180 UAD Statüsünün 38. maddesi bunu Divanın uyuşmazlıkları ele alırken uygulayacağı kaynaklar arasında zikreder. Bu ilkelerin tanımı ve unsurları konusunda görüş birliği olmamakla birlikte, bunların en azından bir yönüyle çoğu hukuk sisteminde/ulusal hukuk düzeninde kabul edilen ortak ilkeleri ifade ettiği belirtilmelidir. Bkz. Akehurst, Michael /Malanczuk, Peter: Akehurst's Modern Introduction to International Law, Gözden Geçirilmiş 7. Baskı, Routledge, 1997, s. 48-50; Boczek, Boleslaw A.: International Law: A Dictionary, The Scarecrow Press Inc., 2005, s. 29; Pazarci, s. 236-241; Sur, s. 88-89. 
$\operatorname{tadır}^{181}$. Üstelik, Avrupa konsensüsünün hukukun genel ilkelerine göre daha gelişmiş ve karmaşı bir kavram olduğu değerlendirilebilir. Zira Avrupa konsensüsü, oldukça spesifik konulara ilişkin olabildiği gibi, Mahkeme tarafından esnek bir biçimde ele alınan ulusal ve uluslararası hukukun çeşitli verilerine hatta bazen genel bir eğilime dayanılarak tespit edilebilmektedir. Mahkeme, Avrupa konsensüsünden doğan bir esasın hukukun genel ilkelerinin gerektirdiği kadar geniş kabul görmesini de aramamaktadır.

Özetle, Avrupa konsensüsünün uluslararası hukukun kaynakları ve yorum kuralları ile birtakım bağlantıları ve benzerlikleri olsa da, bunlar Avrupa konsensüsüne başvurulmasına tam bir dayanak veya açıklama sağlamamaktadır. Mahkemenin genel uygulaması, Avrupa konsensüsüne özel ama sınırları tam belirlenmemiş bir yorum tekniği olarak başvurulduğunu ortaya koymaktadir.

Son olarak, Mahkemenin Sözleşme veya genel uluslararası hukuk çerçevesinde tam karşıllğı olmayan veya açıklanamayan uygulamalarına rağmen, sözleşmeci devletlerin AİHS sistemi içinde kalmaya ve genel olarak AİHM kararlarına uymaya devam etmesinin meşruiyet sorunları açısından bir anlamının olup olmadığı da değerlendirilmelidir. $\mathrm{Bu}$ noktada Dzehtsiarou, haklı olarak, devletlerin kararlara uymasının veya AİHM'nin yetkilerini güçlendiren 11 No'lu Protokolü ve birtakım usulî yenilikler getiren 14 No'lu Protokolü onaylayarak AİHS sistemine desteklerini yenilemesinin, tek başına meşruiyet sorunlarını gidermeyeceğini veya Sözleşmeyi yorumlamada Mahkeme için bütün sınırları kaldırmayacağını belirtmektedir $^{182}$.

\section{SONUÇ}

AİHS'yle üstlenilen taahhütlere uyulmasını Sözleşmenin kurduğu güvence sistemi çerçevesinde sağlamakla yükümlü olan AİHM'nin geliştirdiği "Avrupa konsensüsü” kavramının, tam bir tanımı olmasa da, Mahkemenin kararlarında önemli ve zaman zaman belirleyici bir rol oynadığı görülmektedir. "Ortak payda", "ortak yaklaşım", "ortak standart", "genel eğilim” gibi

181 Yukarıda aktardığımız üzere, Mahkeme ulusal azınlıkların korunması yönünde bir konsensüs ve genel ilke bulunduğunu teyit etse de, karar verilmesi gereken daha spesifik bir durum olduğu için, bunun karara varmada güçlü bir etkisi olmamıştır. Bkz. Case of Chapman v. the United Kingdom, p. 93-94; Case of Lee v. the United Kingdom, p. 9596. Öte yandan mesela Scoppola v. Italya (No. 2) Davasında bir genel ilkeyi (lehe olan ceza normlarının uygulanmasını) teyit eden konsensüsün somut olay hakkındaki kararı doğrudan etkilediği görülmektedir.

182 Dzehtsiarou, s. 145, 151. 
değişik terimlerle belirtilebilen bu kavram, sözleşmeci devletlerin bir kısmının (tercihen önemli bir çoğunluğunun) hukuk ve uygulamalarındaki müşterekliğe/uyuşmaya işaret eder.

Avrupa konsensüsüne özellikle Sözleşmenin yorumlanıp bir hakkın kapsamının belirlenmesi ve devletin Sözleşmeyi uygularken yararlanacağı takdir marjının genişliğinin saptanması amacıyla başvurulmaktadır. Bu bağlamda, sözleşmeci devletlerin hukuk ve uygulamalarının Mahkemenin ele aldığ konuyla ve bu konuya uygulanacak Sözleşme hükmüyle ilgili belirli bir ortak esasın bulunduğunu göstermesi, Mahkemenin söz konusu hakk1 gelişmeci bir yaklaşım çerçevesinde ele almasına; böyle bir esasın yokluğu veya hâlen gelişim aşamasında olması ise, Mahkemenin kendini kısıtlamasına ve davalı devlete daha geniş bir takdir marjı bırakmasına yol açabilmektedir. Genel uygulama böyle olmakla birlikte, konsensüsün varlığı veya yokluğuna otomatik sonuçlar bağlandığı öne sürülemez. Zira Mahkeme, Avrupa konsensüsüne çoğu kez diğer yorum ilke ve yöntemleriyle birlikte başvurmakta ve ayrıca takdir marjının genişliğini ilgili hakkın önemi, konunun hassasiyeti, müdahale edilen faaliyetin niteliği, müdahalenin amac1, koşulları ve ölçüsü gibi başka etkenleri de göz önünde bulundurarak değerlendirmektedir.

Mahkeme konsensüs tekniğini uygularken çoğu kez sözleşmeci devletlerin hukuk ve uygulamalarına gönderme yapmakta; yine birçok durumda bunu desteklemek için uluslararası hukukun çeşitli kaynaklarına da başvurmaktadır. Bununla birlikte, söz konusu tekniğin uygulanma biçiminin bir standarda bağlanmadığı görülmektedir. Mahkemenin uygulaması, her ne kadar ayrı bir araştırma biriminin kurulmasıyla bir ölçüde gelişmiş olsa da, konuyla ilgili bir Avrupa konsensüsünün varlığını tespit etmek için ne düzeyde bir müssterekliğin/uyuşmanın bulunması gerektiğini tam olarak göstermemektedir. Mahkemenin Avrupa konsensüsüne başvururken her zaman açık olmaması, esnek ve tutarsız bir şekilde hareket etmesi, belirsizlik ve güvensizlik yaratıp meşruiyet tartışmalarına yol açabilmektedir.

Bir diğer önemli mesele de AİHM'nin gelişmeci yorumunun ve bu bağlamda başvurduğu Avrupa konsensüsünün hukukî dayanağının ne olduğu hakkındadır. Mahkeme, bazı kararlarında sözleşmeci devletlerin hukuk ve uygulamaları ile uluslararası hukukun kaynaklarına başvururken Andlaşmalar Hukukuna Dair Viyana Sözleşmesi m. 31/3 hükmünün farklı bentlerini zikretse de, bu maddedeki kayıtları pek dikkate almamaktadır. Mahkemenin Avrupa konsensüsünün varlığını tespit ederken gösterdiği esnek yaklaşım, bunun tam anlamiyla örf ve âdet olarak değerlendirilmesine de imkân vermemektedir. Ayrica, hukukun genel ilkeleriyle de bir ölçüde ilgisi bulun- 
makla birlikte Avrupa konsensüsünün oldukça spesifik konulara ilişkin olabildiği ve nisbeten daha gelişmiş ve karmaşık bir içeriğe sahip olduğu belirtilmelidir.

Mahkemenin genel uygulaması, Avrupa konsensüsüne içtihatlarla benimsenen gelişmeci yorum ilkesine dayanarak ve özel bir yorum tekniği olarak başvurulduğunu ortaya koymaktadır. Ne var ki, Avrupa konsensüsünün uluslararası hukukun kaynakları ve yorum kurallarıyla birtakım bağlantı ve benzerlikleri olsa da bunlar Avrupa konsensüsüne tam bir dayanak ve açıklama sağlamadığı için, hakları geliştirmek amacıyla bu tekniğe başvurulmasının meşruiyeti tartışmaya açık kalmaktadır.

Avrupa konsensüsünün, uygulanma biçimi ve bizzat esası bakımından birtakım belirsizlikler bulunmakla birlikte, AİHM kararlarında önemli bir yer tutmaya ve etkisini arttırmaya devam ettiği görülmektedir. AİHS sisteminin gerek normatif ve yapısal değişikliklerle gerek içtihatlarla güçlendirilmesi, sözleşmeci devletlerin sistem içinde kalma iradelerini sürdürmelerini engellememiştir. Salt hukukî gerekliliklerin yanında devletlerin bağlılığının devamı için de, AİHM'nin en azından konsensüs tekniğini geliştirerek ve mümkün mertebe tutarlı bir şekilde uygulaması gerekmektedir. 


\section{KAYNAKÇA}

\section{Kitaplar - Makaleler}

Akehurst, Michael/Malanczuk, Peter: Akehurst's Modern Introduction to International Law, Gözden Geçirilmiş 7. Bask1, Routledge, 1997.

Altıparmak, Kerem/Karahanoğlulları, Onur: "Pyrrhus Zaferi: Leyla Şahin v. Türkiye, AİHM v. Hukuk, Düzenleyici İşlem v. Kanun”, Hukuk ve Adalet Dergisi, Temmuz-Eylül 2004, S. 3, s. 249-275.

Arai-Takahashi, Yutaka: "The Margin of Appreciation Doctrine: A Theoretical Analysis of Strasbourg's Variable Geometry", in: Andreas Føllesdal/Birgit Peters/Geir Ulfstein (eds.), Constituting Europe: The European Court of Human Rights in a National, European and Global Context, Cambridge University Press, 2013, s. 62-105.

Aybay, Rona/Oral, Elif: Kamusal Uluslararası Hukuk, İstanbul Bilgi Üniversitesi Yayınları, 2016.

Benvenisti, Eyal: "Margin of Appreciation, Consensus and Universal Standards", New York University Journal of International Law \& Politics, 1998-1999, Vol. 31, s. 843-854.

Black's Law Dictionary, Bryan A. Garner (ed.), 9. Bask1, West Publishing Co., 2009.

Boczek, Boleslaw A.: International Law: A Dictionary, The Scarecrow Press Inc., 2005.

Brauch, Jeffrey A.: "The Dangerous Search for and Elusive Consensus: What the Supreme Court Should Learn from the European Court of Human Rights", Howard Law Journal, 2008-2009, Vol. 52, s. 277-318.

Brems, Eva: "The Margin of Appreciation Doctrine in the Case-Law of the European Court of Human Rights", Zeitschrift für ausländisches öffentliches Recht und Völkerrecht, 1996, Vol. 56, s. 240-314.

Çavuşoğlu, Naz: “İnsan Hakları Avrupa Sözleşmesi'ni 'Yaşayan Belge' Yapan Yorum Teknikleri”, İnsan Hakları Y1llı̆̆1, 1992, S. 14, s. 131146.

Dijk, P. van/Hoof, G. J. H. Van: Theory and Practice of the European Convention on Human Rights, 3. Bask1, Kluwer Law International, 1998. 
Doğru, Osman/Nalbant, Atilla: İnsan Hakları Avrupa Sözleşmesi: Açıklama ve Önemli Kararlar, C. 2: İHAS 8, 9, 10, 11, 12, 13, 14, Ek Protokol 11, 1-2, 1-3 Maddeler, Council of Europe/TC Yargıtay Başkanlığı, 2013.

Dzehtsiarou, Kanstantsin: European Consensus and the Legitimacy of the European Court of Human Rights, Cambridge University Press, 2015.

Forowicz, Magdalena: The Reception of International Law in the European Court of Human Rights, Oxford University Press, 2010.

Gözübüyük, Şeref/Gölcüklü, Feyyaz: Avrupa İnsan Hakları Sözleşmesi ve Uygulamas1, 5. Bask1, Turhan, 2004.

Greer, Steven: The Margin of Appreciation: Interpretation and Discretion under the European Convention on Human Rights, Council of Europe Publishing, 2000.

Gündüz, Aslan: Milletlerarası Hukuk Temel Belgeler Örnek Kararlar, 5. Bask1, Beta, 2003.

Harris, David/O'Boyle, Michael/Bates, Ed/Buckley, Carla: Harris, O’Boyle and Warbrick's Law of the European Convention on Human Rights, 2. Bask1, Oxford University Press, 2009.

Helfer, Laurence R.: "Consensus, Coherence and the European Convention on Human Rights", Cornell International Law Journal, 1993, Vol 26, s. 133-165.

Higgins, Rosalyn: "Time and the Law: International Perspectives on an Old Problem", International and Comparative Law Quarterly, 1997, Vol. 46, s. 501-520.

Hill-Cawthorne, Lawrence: "The Grand Chamber Judgment in Hassan v. UK", EJIL: Talk!, 16.09.2014. Erişim: https://www.ejiltalk.org/thegrand-chamber-judgment-in-hassan-v-uk/.

Jacobs, Francis G./White, Robin C. A.: The European Convention on Human Rights, 2. Bask1, Clarendon Press, 1996.

Letsas, George: "The ECHR as a Living Instrument: Its Meaning and Legitimacy", in: Andreas Føllesdal/Birgit Peters/Geir Ulfstein (eds.), Constituting Europe: The European Court of Human Rights in a National, European and Global Context, Cambridge University Press, 2013, s. 106-141.

Londras, Fiona de/Dzehtsiarou, Kanstantsin: Great Debates on the European Convention on Human Rights, Palgrave Macmillan, 2018. 
Merrills, J. G.: The Development of International Law by the European Court of Human Rights, Manchester University Press, 1988.

Pazarcı, Hüseyin: Uluslararası Hukuk Dersleri, 1. Kitap, Gözden Geçirilmiş 12. Bask1, Turhan Kitabevi, 2014.

Schabas, William: The European Convention on Human Rights: A Commentary, Oxford University Press, 2015.

Senden, Hanneke Ceciel Katrijn: Interpretation of Fundamental Rights in a Multilevel Legal System: An Analysis of the European Court of Human Rights and the Court of Justice of the European Union, Doktora Tezinin Yayımlanmamış Hâli, Leiden University, 2011.

Sur, Melda: Uluslararası Hukukun Esasları, Gözden Geçirilmiş 12. Bask1, Beta, 2018.

Tezcan, Durmuş/Erdem, Mustafa Ruhan/Sancakdar, Oğuz: Avrupa İnsan Hakları Sözleşmesi Işs̆̆ında Türkiye'nin İnsan Hakları Sorunu, 2. Baskı, Seçkin, 2004.

The American Heritage Dictionary of the English Language, 3. Bask1, Houghton Mifflin Co., 1992.

Vanneste, Frédéric: General International Law before Human Rights Courts: Assessing the Specialty Claims of International Human Rights Law, Intersentia, 2010.

Wildhaber, Luzius/Hjartarson, Arnaldur/Donnelly, Stephen: "No Consensus on Consensus? The Practice of the European Court of Human Rights”, Human Rights Law Journal, 2013, Vol. 33, s. 248-263.

Ziemele, Ineta: "European Consensus and International Law", in: Anne van Aaken/Iulia Motoc (eds.), The European Convention on Human Rights and General International Law, Oxford University Press, 2018, s. 2340.

\footnotetext{
AİHM Kararları

Case of $A, B$ and $C$ v. Ireland, ECHR (Grand Chamber), Judgment of 16.12.2010.

Case of Bayatyan v. Armenia, ECHR (Grand Chamber), Judgment of 07.07.2011.

Case of Berkovich and Others v. Russia, ECHR (Third Section), Judgment of 27.03.2018 (final 27.06.2018).
} 
Case of Chapman v. the United Kingdom, ECHR (Grand Chamber), Judgment of 18.01.2001.

Case of Christine Goodwin v. the United Kingdom, ECHR (Grand Chamber), Judgment of 11.07.2002.

Case of Comingersoll S.A. v. Portugal, ECHR (Grand Chamber), Judgment of 06.04.2000.

Case of Cossey v. the United Kingdom, ECHR (Plenary), Judgment of 27.09.1990.

Case of Cruz Varas and Others v. Sweden, ECHR (Plenary), Judgment of 20.03.1991.

Case of Demir and Baykara v. Turkey, ECHR (Grand Chamber), Judgment of 12.11.2008.

Case of Dickson v. the United Kingdom, ECHR (Grand Chamber), Judgment of 04.12.2007.

Case of E.B. v. France, ECHR (Grand Chamber), Judgment of 22.01.2008.

Case of Evans v. the United Kingdom, ECHR (Grand Chamber), Judgment of 10.04.2007.

Case of Fabris v. France, ECHR (Grand Chamber), Judgment of 07.02.2013.

Case of Fretté v. France, ECHR (Third Section), Judgment of 26.02.2002 (final 26.05.2002).

Case of Glor v. Switzerland, ECHR (First Section), Judgment of 30.04.2009 (final 06.11.2009).

Case of Golder v. the United Kingdom, ECHR (Plenary), Judgment of 21.02.1975.

Case of Golder v. the United Kingdom, ECHR (Plenary), Separate Opinion of Judge Sir Gerald Fitzmaurice of 21.02.1975.

Case of Golder v. the United Kingdom, ECHR (Plenary), Separate Opinion of Judge Verdross of 21.02.1975.

Case of Handyside v. the United Kingdom, ECHR (Plenary), Judgment of 07.12.1976.

Case of Hassan v. the United Kingdom, ECHR (Grand Chamber) Judgment of 16.09.2014.

Case of Hirst v. the United Kingdom (No. 2), ECHR (Grand Chamber), Judgment of 06.10.2005. 
Case of Hristozov and Others v. Bulgaria, ECHR (Fourth Section), Judgment of 13.11.2012 (final 29.04.2013).

Case of Ibrogimov v. Russia, ECHR (Third Section Committee), Judgment of 15.05.2018.

Case of Ireland v. the United Kingdom, ECHR (Plenary), Judgment of 18.01.1978.

Case of James and Others v. the United Kingdom, ECHR (Plenary), Judgment of 21.02.1986.

Case of Kafkaris v. Cyprus, ECHR (Grand Chamber), Judgment of 12.02.2008.

Case of Kearns v. France, ECHR (Third Section), Judgment of 10.01.2008.

Case of Khamtokhu and Aksenchik v. Russia, ECHR (Grand Chamber), Judgment of 24.01.2017.

Case of Kimlya and Others v. Russia, ECHR (First Section), Judgment of 01.10.2009 (rectified on 03.12.2009) (final 01.03.2010).

Case of Kiyutin v. Russia, ECHR (First Section), Judgment of 10.03.2011 (final 15.09.2011).

Case of Lautsi and Others v. Italy, ECHR (Grand Chamber), Dissenting Opinion of Judge Malinverni joined by Judge Kalaydjieva of 18.03.2011.

Case of Lautsi and Others v. Italy, ECHR (Grand Chamber), Judgment of 18.03.2011.

Case of Lee v. the United Kingdom, ECHR (Grand Chamber), Judgment of 18.01.2001.

Case of Leyla Şahin v. Turkey, ECHR (Grand Chamber), Dissenting Opinion of Judge Tulkens of 10.11.2005.

Case of Leyla Şahin v. Turkey, ECHR (Grand Chamber), Judgment of 10.11.2005.

Case of Loizidou v. Turkey (Preliminary Objections), ECHR (Chamber), Judgment of 23.03.1995.

Case of M.C. v. Bulgaria, ECHR (First Section), Judgment of 04.12.2003 (final 04.03.2004).

Case of Mamatkulov and Askarov v. Turkey, ECHR (Grand Chamber), Judgment of 04.02.2005.

Case of Marckx v. Belgium, ECHR (Plenary), Judgment of 13.06.1979. 
Case of Micallef v. Malta, ECHR (Grand Chamber), Judgment of 15.10.2009.

Case of Naït-Liman v. Switzerland, ECHR (Grand Chamber), Judgment of 15.03.2018.

Case of Niemietz v. Germany, ECHR (Chamber), Judgment of 16.12.1992.

Case of Novruk and Others v. Russia, ECHR (Third Section), Judgment of 15.03.2016 (final 15.06.2016).

Case of Odièvre v. France, ECHR (Grand Chamber), Joint Dissenting Opinion of Judges Wildhaber, Sir Nicolas Bratza, Bonello, Loucaides, Cabral Barreto, Tulkens and Pellonpää of 13.02.2003.

Case of Odièvre v. France, ECHR (Grand Chamber), Judgment of 13.02.2003.

Case of Rantsev v. Cyprus and Russia, ECHR (First Section), Judgment of 07.01.2010 (final 10.05.2010).

Case of Rasmussen v. Denmark, ECHR (Chamber), Judgment of 28.11.1984.

Case of Rees $v$. the United Kingdom, ECHR (Plenary), Judgment of 17.10.1986.

Case of Rohlena v. the Czech Republic, ECHR (Grand Chamber), Judgment of 27.01.2015.

Case of S.A. Dangeville v. France, ECHR (Second Section), Judgment of 16.04.2002 (final 16.07.2002).

Case of S.A.S. v. France, ECHR (Grand Chamber), Judgment of 01.07.2014.

Case of S.H. and Others v. Austria, ECHR (Grand Chamber), Judgment of 03.11.2011.

Case of Salesi v. Italy, ECHR (Chamber), Judgment of 26.02.1993.

Case of Satık v. Turkey (No. 2), ECHR (Third Section), Judgment of 08.07.2008 (final 08.10.2008).

Case of Schalk and Kopf v. Austria, ECHR (First Section), Judgment of 24.06.2010 (final 22.11.2010).

Case of Schwizgebel v. Switzerland, ECHR (First Section), Judgment of 10.06.2010 (final 10.09.2010).

Case of Scoppola v. Italy (No. 2), ECHR (Grand Chamber), Judgment of 17.09.2009.

Case of Selmouni v. France, ECHR (Grand Chamber), Judgment of 28.06.1999. 
Case of Sheffield and Horsham v. the United Kingdom, ECHR (Grand Chamber), Judgment of 30.07.1998.

Case of Shindler v. the United Kingdom, ECHR (Fourth Section), Judgment of 07.05.2013 (final 09.09.2013).

Case of Sigurdur A. Sigurjónsson v. Iceland, ECHR (Chamber), Judgment of 30.06.1993.

Case of Siliadin v. France, ECHR (Second Section), Judgment of 26.07.2005 (final 26.10.2005).

Case of Soering $v$. the United Kingdom, ECHR (Plenary), Judgment of 07.07.1989.

Case of Stec and Others v. the United Kingdom, ECHR (Grand Chamber), Judgment of 12.04.2006.

Case of Stoll v. Switzerland, ECHR (Grand Chamber), Judgment of 10.12.2007.

Case of Stubbings and Others v. the United Kingdom, ECHR (Chamber), Judgment of 22.10.1996.

Case of Stummer v. Austria, ECHR (Grand Chamber), Judgment of 07.07.2011.

Case of Stübing v. Germany, ECHR (Fifth Section), Judgment of 12.04.2012 (rectified on 13.04.2012) (final 24.09.2012).

Case of Sunday Times v. the United Kingdom (No. 1), ECHR (Plenary), Judgment of 26.04.1979.

Case of T. v. the United Kingdom, ECHR (Grand Chamber), Joint Partly Dissenting Opinion of Judges Pastor Ridruejo, Ress, Makarczyk, Tulkens and Butkevych of 16.12.1999.

Case of T. v. the United Kingdom, ECHR (Grand Chamber), Judgment of 16.12.1999.

Case of Tyrer v. the United Kingdom, ECHR (Chamber), Judgment of 24.04.1978.

Case of Ünal Tekeli v. Turkey, ECHR (Fourth Section), Judgment of 16.11.2004 (final 16.02.2005).

Case of Vallianatos and Others v. Greece, ECHR (Grand Chamber), Judgment of 07.11.2013.

Case of Van der Mussele v. Belgium, ECHR (Plenary), Judgment of 23.11.1983. 
Case of Vo v. France, ECHR (Grand Chamber), Judgment of 08.07.2004.

Case of Wemhoff v. Germany, ECHR (Chamber), Judgment of 27.06.1968.

Case of $X$ and Others v. Austria, ECHR (Grand Chamber), Joint Partly Dissenting Opinion of Judges Casadevall, Ziemele, Kovler, Jočiene, Šikuta, De Gaetano, and Sicilianos of 19.02.2013.

Case of $X, Y$ and $Z$ v. the United Kingdom, ECHR (Grand Chamber), Concurring Opinion of Judge De Meyer of 22.04.1997.

Case of $X, Y$ and $Z v$. the United Kingdom, ECHR (Grand Chamber), Judgment of 22.04.1997.

Case of Yumak and Sadak v. Turkey, ECHR (Grand Chamber), Judgment of 08.07.2008.

\section{Diğer Belgeler}

"Draft Conclusions on Subsequent Agreements and Subsequent Practice in relation to the Interpretation of Treaties, with Commentaries", Yearbook of the ILC, 2018, Vol. 2, Part 2.

European Court of Human Rights/Jurisconsult, "Interlaken Follow-Up: Principle of Subsidiarity”, 08.07.2010.

\section{İnternet Siteleri}

http://www.echr.coe.int/

https://www.icj-cij.org/ 